(C) <2019>. This manuscript version is made available under the CC-BY-NC-ND 4.0 license http://creativecommons.org/licenses/by-nc-nd/4.0/

The definitive publisher version is available online at 10.1016/j.desal.2018.10.013 


\title{
Applications of Capacitive Deionization (CDI): Desalination, Softening, Selective Removal, and Energy Efficiency
}

\author{
Desalination \\ Revised \\ May \#\#, 2018
}

Jongmoon $\mathrm{Choi}^{1}$, Pema Dorji ${ }^{2}$, Ho Kyong Shon ${ }^{2 *}$, and Seungkwan Hong ${ }^{1 * *}$

${ }^{1}$ School of Civil, Environmental and Architectural Engineering, Korea University, 1-5 Ga, Anam-Dong, Seongbuk-Gu, Seoul, 136-713, Republic of Korea

${ }^{2}$ School of Civil and Environmental Engineering, University of Technology, Sydney (UTS), City Campus, Broadway, NSW 2007, Australia

\footnotetext{
*Co-corresponding author. Tel.: +61 29514 2629; E-mail: Hokyong.Shon-1@uts.edu.au

${ }^{* * *}$ Corresponding author. Tel.: +82-2-3290-3322; E-mail: skhong21@ korea.ac.kr
} 


\section{Outline}

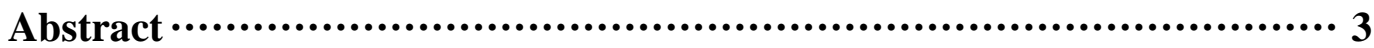

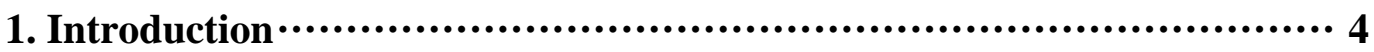

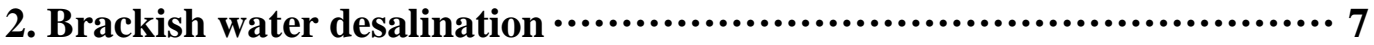

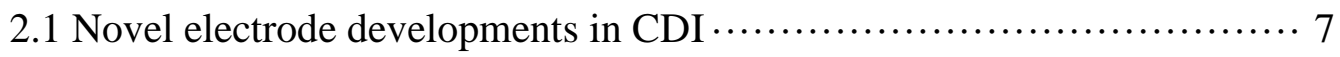

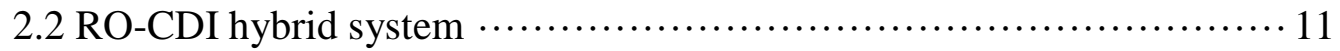

2.2.1 RO-CDI pass systems (UPW production) $\cdots \cdots \cdots \ldots \ldots \ldots \ldots \ldots \ldots \ldots \ldots \ldots \ldots \ldots \ldots$

2.2.2 RO-CDI stage systems (Wastewater treatment) $\cdots \ldots \ldots \ldots \ldots \ldots \ldots \ldots \ldots \ldots \ldots$

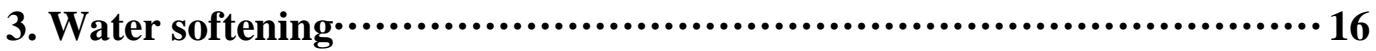

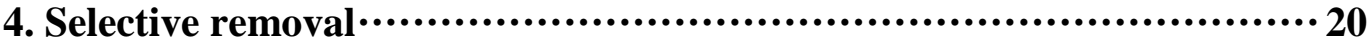

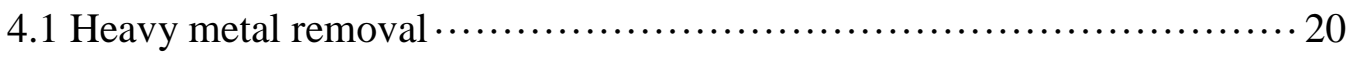

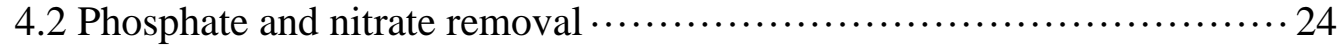

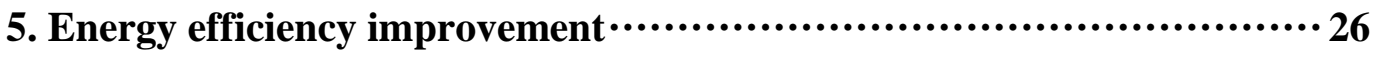

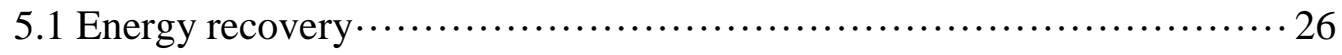

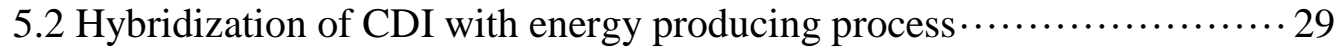

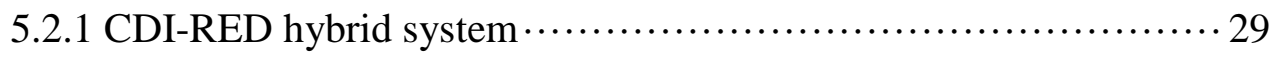

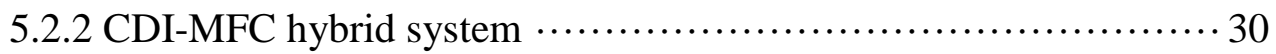

6. Challenges in CDI technology: fouling, scaling, and scale-up $\cdots \cdots \cdots \cdots \cdots 33$

7. Perspectives and outlook for expanding the CDI applications $\cdots \cdots \cdots \cdots \cdots 34$

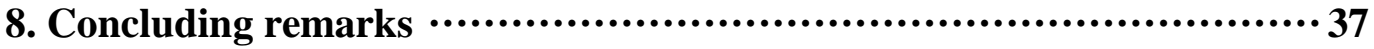

Acknowledgements

References 


\begin{abstract}
Capacitive deionization (CDI) has drawn a great attention as a promising desalination technology and due to the great potential, studies on CDI are now significantly increased. However, there have been no guideline of the developing strategies of the CDI technology for specific applications. Therefore, this study presents a critical review of the recent advances in CDI to meet the technical requirements on various applicable areas, with an emphasis on a hybrid system. This review paper summarizes the major progresses on the novel electrode materials in CDI for the brackish water desalination application. Moreover, it reviews the CDI and reverse osmosis (RO) integrated systems for both ultrapure water (UPW) production and the wastewater treatment. The CDI applicability on various industrial processes has been further discussed through two distinctive areas: (1) water softening and (2) selective removal for valuable heavy metals and nutrients (nitrate/phosphate). Additionally, it summarizes the outstanding improvements on energy efficiency of CDI, specifically focusing on the energy recovery and hybridization with energy producing technology (i.e., reverse electrodialysis (RED) and microbial fuel cell (MFC)). This review paper is expected to suggest the practical applications and guidelines for electrode material developments on specific applications.
\end{abstract}

Keywords: Capacitive deionization, Applications, Hybrid system, Energy efficiency, Selective removal, Desalination 


\section{Introduction}

Utilizing the non-conventional water resources for drinking water production is inevitable in these days [1]. As an alternative to the sustainable water resources, brackish water desalination is considered to be one of the key strategic solutions to the increasing fresh water demand. Today, numerous processes have been applied for brackish water desalination: membrane based pressure driven (i.e., reverse osmosis (RO) and nanofiltration (NF)) and electrochemically driven (i.e., electrodialysis (ED) and (electrodeionization (EDI)) processes are by far the dominant technologies producing fresh water from various water resources $[2$, 3]. Although significant improvement of desalination technologies has been achieved, limitations such as high energy consumption and/or membrane fouling have been reported to be the critical problem $[4,5]$. Therefore capacitive deionization (CDI), an electrochemical process removing the salt or charged species from the feed solution by the porous electrodes has emerged as the next-generation desalination technique [6].

The principle of CDI process relies on the electrical potential difference over a pair of electrodes to remove the charged species from the water. The removal mechanism of CDI is represented by the electrical double layer models in which ion removal is induced by electrosorption on the electrodes $[7,8]$. As the absence of hydraulic pressure not only implies the potential to reduce operating cost but can also be beneficial for fouling control, compared to the pressure-driven membrane processes. Furthermore, relatively low voltage is required for CDI (less than $1.8 \mathrm{~V}$ ) over conventional electrochemical-driven processes, as a result, CDI displays significant advantages in terms of low energy requirements with substantial water recovery [9]. It should be noted that when the applied voltage exceeds certain point (theoretically $1.23 \mathrm{~V}$, causing water hydrolysis), Faradaic reaction was occurred, which could 
be followed by the decreased desalination performance, energy efficiency, and electrode lifespan [10].

In recent years, CDI technology has been developed for improving both removal and energy efficiency with advanced CDI system called membrane-CDI (MCDI) and flow electrode-CDI (FCDI). MCDI, modified CDI system with integrating ion exchange membranes on the surface of the electrodes exhibited superior desalination performance compared to conventional CDI due to preventing the impact of co-ions [11-13]. More recently FCDI exhibits great potential for being the next-generation CDI system $[14,15]$. As the FCDI process utilizes the flowing suspended carbon electrode materials, salts could be continuously desalinated, that is, no discharging stage is required.

Numerous CDI research areas have been conducted and a total of 536 papers were published since 2012, as depicted in Fig. 1. Most of the CDI studies focused on the electrode development (54.5\%), followed by CDI applications (19.6\%), whereas the rest are dedicated to better understand the energy efficiency, fundamental mechanisms, and novel systems. Specifically, a total of 15 review papers related to CDI have been published in the last five years, which strongly indicates the rapid evolution of the CDI technology. As per the most of the earlier research papers, published review papers also focus on the recent advantages on the electrode material development. Other review papers summarized the overall aspects of CDI technology. However, there have been few studies on suggesting guidelines for practical applications of CDI technology. 

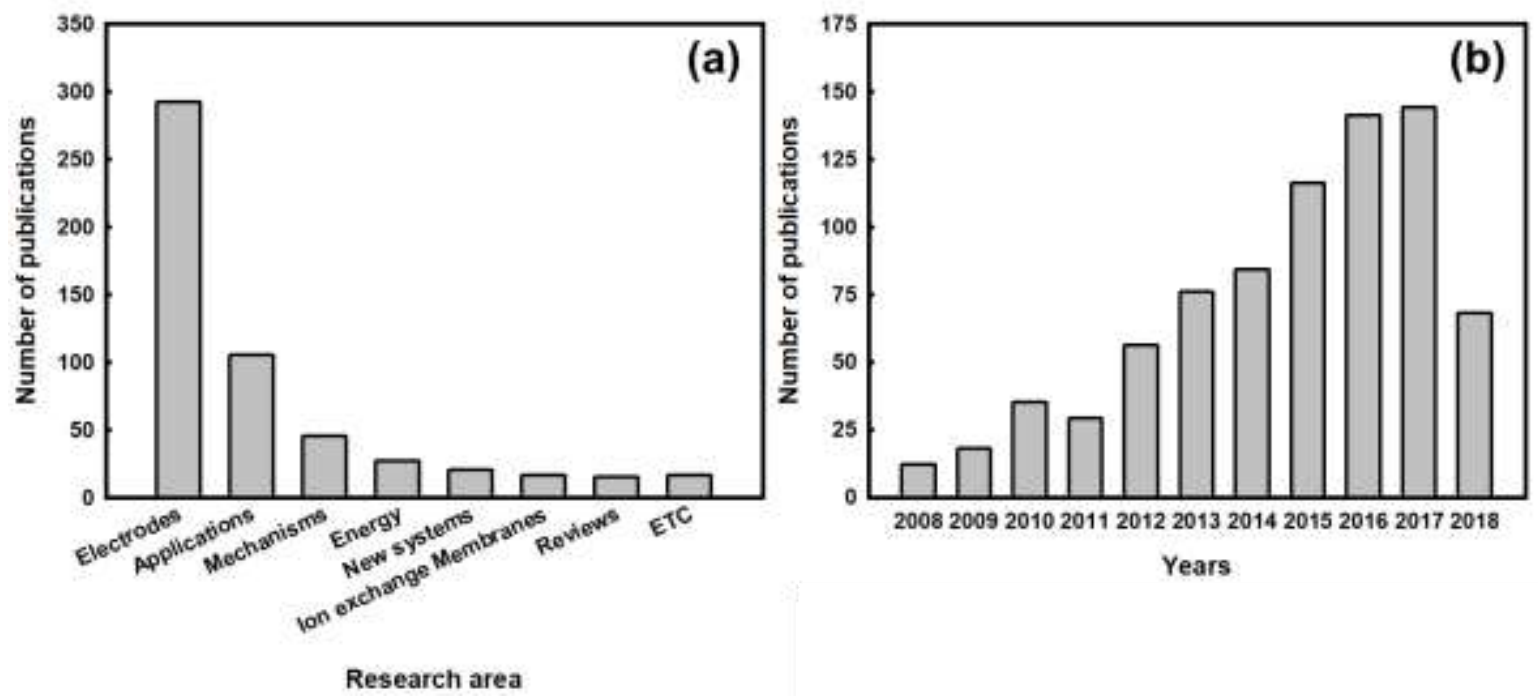

Figure 1 The number of publications depending on (a) the research areas of the CDI technology (2012-2017) and (b) the published year. Research papers were retrieved from the Scopus with capacitive deionization as the keyword in the title and the papers published in only past five years were categorized for research area analysis (Access on March 2018).

Therefore, this paper reviewed the practical applicability by treating various feed solutions with CDI strengths in terms of (i) brackish water desalination, (ii) water softening, (iii) selective removal (i.e., heavy metals or phosphate/nitrate), and (iv) energy efficiency as depicted in Fig. 2. This review paper is considered to suggest practical application areas and guideline on developing the CDI process for specific applications. For improving the desalination performance and energy efficiency, the hybrid system of CDI with other technologies (i.e., RO, reverse electrodialysis (RED), or microbial fuel cell (MFC)) were critically discussed. 


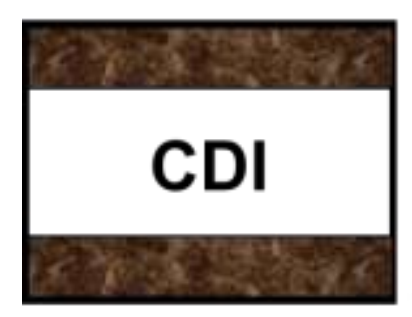

Energy efficiency improvement

\section{Application areas}

- Energy recovery

- Hybridization
Brackish water desalination

Water softening

Nutrients removal

(Nitrate and/or phosphate)

Heavy metal removal

Figure 2 Possible application areas of CDI technology and practical strategies to improve the energy efficiency.

\section{Brackish water desalination}

\subsection{Novel electrode developments in CDI}

Electrode material development is one of the most fundamental solutions for higher desalination capacity as well as the removal efficiency of CDI process and therefore, the majority of recent studies focused on the development and synthesis of superior electrode material. Significant efforts have been made to develop high performance electrodes by synthesizing different carbon based materials such as activated carbon, carbide derived carbon (CDC), carbon aerogel, carbon nanotubes (CNTs), carbon nanofibers (CNFs), composites, graphene, etc. (Table 1).

Activated carbon was considered to be the most common electrode material due to its high surface area and optimized pore size distribution for the CDI process with relatively cheap and easy manufacturing characteristics [16]. However for better removal efficiency, other aforementioned materials have been widely investigated as the next generation electrodes due to (1) improved surface area (carbide-derived carbon (CDC) for about $1100-1300 \mathrm{~m}^{2} / \mathrm{g}$, graphene for $2630 \mathrm{~m}^{2} / \mathrm{g}$, and CNT for 77,415 m²/g) [17-19], (2) high salt adsorption capacity 
(CDC for $28-44 \%$ increment) [17], (3) low electrical resistivity (carbon aerogel for <40 $\mathrm{m} \Omega / \mathrm{cm}$ ) [20], or (4) optimized pore size distribution (carbon aerogel for $<50 \mathrm{~nm}$ ) [21]. Furthermore, anion and cation exchange polymers integrated with CNTs electrodes were fabricated. It showed much higher removal efficiency (93\%) compared to that of CDI (25\%) or MCDI (74\%) [22].

As summarized in Table 1, great efforts have been conducted on improving the performance of CDI by employing the novel electrodes. The newly synthesized or developed electrodes exhibited innovative removal efficiency, however, essence lies not only on the improved electrode performance but on the commercialization (i.e., cheap and easy to scale up). That is the reason why most of the companies Voltea (Nederland), EST Water \& Technologies CO., Ltd (China), and Siontech (South Korea) supplying CDI units manufactured the CDI modules with the conventional activated carbon. Therefore consideration for feasibility of novel electrode on practical implication should be accompanied with improving the removal performance. 
Table 1 Salt adsorption rate and removal efficiency of different types of CDI electrode materials and system types. As the salt adsorption rate and removal efficiency results were obtained from the lab-scale experiments, capacity of the CDI system was not stated.

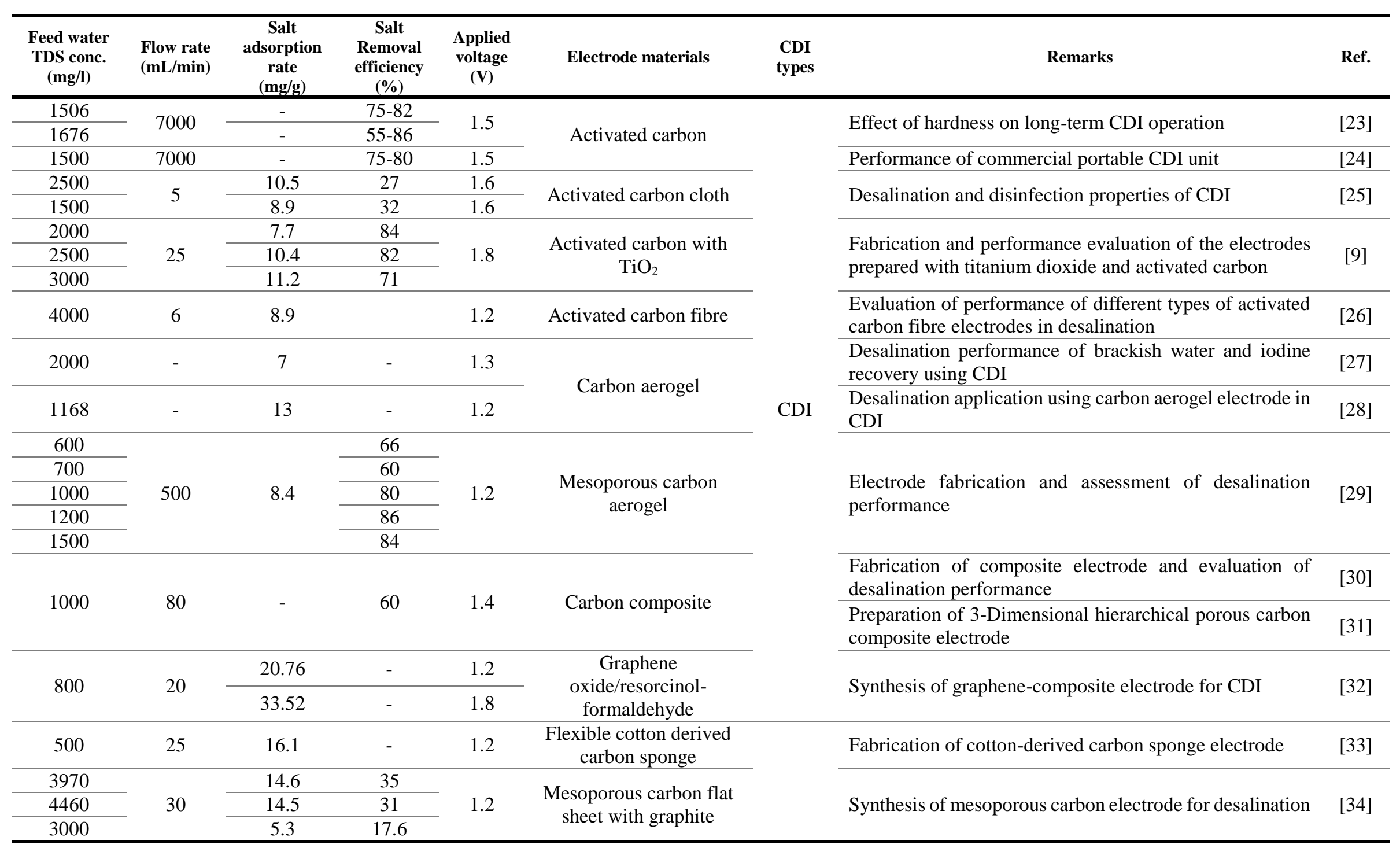




\begin{tabular}{|c|c|c|c|c|c|c|c|c|}
\hline 1000 & - & 78.73 & - & 1.4 & Polypyrrole/graphite & & $\begin{array}{l}\text { Investigation of dopants on the adsorbing performance of } \\
\text { polypyrrole/graphite electrodes for CDI }\end{array}$ & [35] \\
\hline 500 & 1000 & - & 90.6 & - & \multirow{2}{*}{ Activated carbon } & \multirow{6}{*}{ MCDI } & $\begin{array}{l}\text { Study demonstrating energy recovery potential of MCDI } \\
\text { during desorption phase }\end{array}$ & [36] \\
\hline 503 & - & - & 70 & - & & & $\begin{array}{l}\text { Practical application of MCDI for desalination of cooling } \\
\text { tower feed water }\end{array}$ & [37] \\
\hline 1000 & 40 & - & 92 & 1.2 & Activated carbon cloth & & performance comparison between CDI and MCDI & [38] \\
\hline- & 40 & & 93.5 & 1.6 & $\begin{array}{l}\text { Carbon nanotube- } \\
\text { nanofibre }\end{array}$ & & $\begin{array}{l}\text { Fabrication of carbon nanotube-carbon fibre composite } \\
\text { electrode for MCDI desalination }\end{array}$ & [39] \\
\hline - & 50 & 5.6 & 93 & 1.2 & Carbon nanotubes & & $\begin{array}{l}\text { Incorporation of ion exchange polymer directly on the } \\
\text { electrode as modified MCDI }\end{array}$ & [22] \\
\hline 1000 & 9 & & 90 & 1.2 & Carbon fibre & & $\begin{array}{l}\text { Performance of different types of ion exchange } \\
\text { membranes on MCDI }\end{array}$ & [40] \\
\hline
\end{tabular}




\subsection{RO-CDI hybrid system}

RO technology takes a significant place in desalination due to its excellent salt rejection, despite of some drawbacks, in terms of membrane fouling/scaling and high energy consumption. On the contrary, CDI can supplement the limitations of RO process and therefore integrating these two processes, RO-CDI hybrid system can improve the performance and energy efficiency which can possibly replace the conventional RO system. Two scenarios of RO-CDI hybrid systems: (1) RO-CDI pass system (CDI as RO permeate treatment) for ultrapure water (UPW) production and (2) RO-CDI stage system (CDI as RO brine treatment) for maximizing water recovery rate in wastewater treatment were critically discussed as below.

\subsubsection{RO-CDI pass system (UPW production)}

These days, for stringent drinking water regulation and increased demand for highly purified water for industrial areas, auxiliary processes for further RO permeate treatment is essential [41]. UPW, where the contaminants are removed to extremely low levels, is used in many industries such as power plants, pharmaceutical industries, etc. As such, the demand and market potential for UPW is on the rise [41] and the two-pass RO system is now widely adopted to meet the required water quality. Despite its high removal efficiency of the two-pass RO system, composed of first-pass RO and second-pass brackish water RO (BWRO) (Fig. 3(a)), high energy consumption has explored a new system. Therefore, RO-CDI pass system has been suggested to replace the conventional two-pass RO system (Fig. 3(b)). 


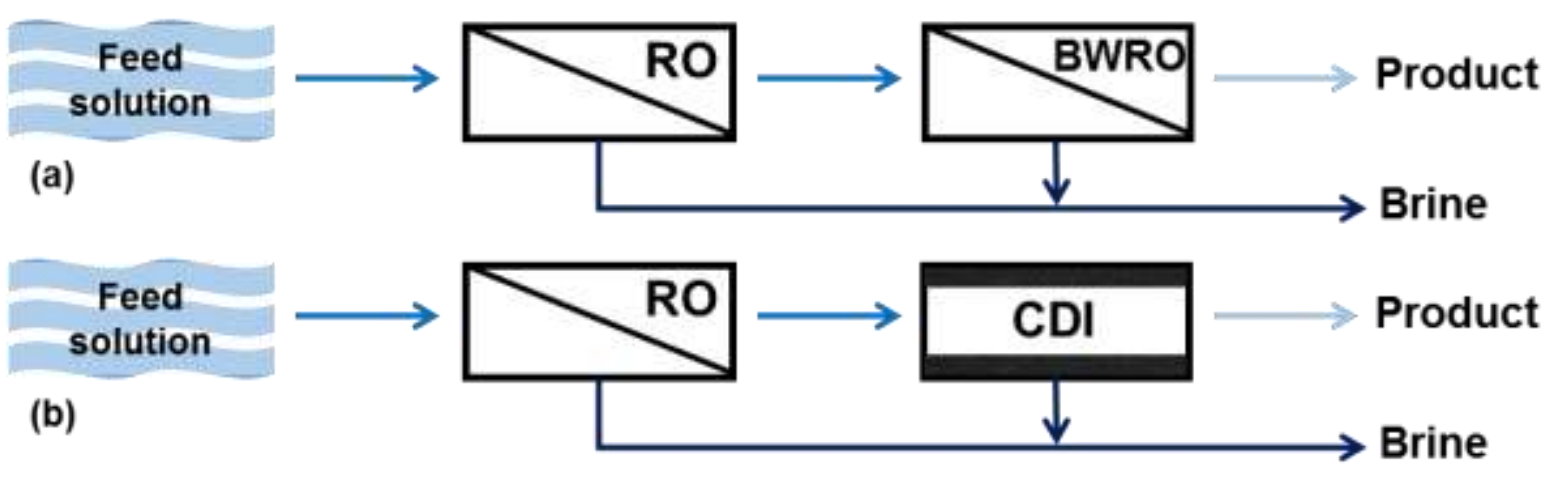

Figure 3 Schematic diagram of (a) conventional two pass RO and (b) RO-CDI pass system for producing the UPW. In RO-CDI pass system, RO permeate is further treated by the CDI process to achieve extremely high permeate water quality such as UPW.

Several studies demonstrated the CDI application potential for UPW production. An introduction of $\mathrm{CDI}$ as $\mathrm{RO}$ permeate polishing step can be an alternative solution due to the great energy efficiency [15, 41-43]. Furthermore, there should be little concerns on organic or inorganic fouling [44], which are the two main pollutant groups in the water as the feed water to CDI. Therefore, performance of CDI could be maximized without any fouling or scaling problems. In this respect, RO-CDI pass system was investigated to produce not only drinking water but also highly purified water such as UPW [42].

Previous studies simulated the water quality of UPW and fresh water from the RO-CDI pass system. With the increase of the feed solution concentrations, TDS concentrations of UPW and fresh water were gradually increased. Furthermore, by optimizing the system configuration and improving the CDI performance, TDS concentration of the UPW was drastically dropped to $0.035 \mathrm{mg} / \mathrm{L}$ (resistivity as $18.8 \mathrm{M} \Omega / \mathrm{cm}$ ) which could be used for semiconductor industry requiring the highest level of purity [41]. Furthermore, performance of the CDI was investigated under $10 \mathrm{mg} / \mathrm{L}$ of the feed solution TDS concentration and the UPW with resistivity from 2 to $9 \mathrm{M} \Omega / \mathrm{cm}$ was produced under $1.5 \mathrm{~V}$ of the applied voltage [45]. Another 
research simulated that a permeate quality of $2.1 \mathrm{mg} / \mathrm{L}$ can be produced even from the seawater $(32,702 \mathrm{mg} / \mathrm{L})$ with a removal efficiency of $99.9 \%$ [46].

Advanced researches exhibited a great potential of the RO-CDI pass system for substituting the conventional RO-EDI system with satisfactory product water quality and energy efficiency. EDI, combined with ED and ion exchange resin, is currently the most common process employed for UPW production system. Although EDI could produce extremely highly purified produced water, specific energy consumption (SEC) of EDI (0.39$\left.2.11 \mathrm{kWh} / \mathrm{m}^{3}\right)$ was relatively higher than that of CDI process $\left(0.02-0.22 \mathrm{kWh} / \mathrm{m}^{3}\right)$ depending on the applied voltage, flow rate, and feed solution TDS concentration [43, 47]. Another possible application of RO-CDI pass system could be bromide removal in seawater desalination. Recent study reported that adopting CDI on behalf of the conventional BWRO as the second pass process could decrease the energy consumption up to $40 \%$ when treating the 1st pass RO permeate [48]. There was no direct comparison of the cost related to capital investment between CDI and BWRO, however, feasibility of RO-CDI pass system for seawater desalination was definitely proved.

Previous studies convinced the successful application of the CDI process as the RO-CDI pass system for the UPW production as well as other various industrial applications due to the competent removal and energy efficiency. However, as most of the results were obtained from the simulation, further researches through the lab- and real-scale experiment should be investigated.

\subsubsection{RO-CDI stage system (Wastewater treatment)}


Besides the seawater desalination, RO recently broadens its application to industrial and municipal wastewater treatment. However, the production of RO brine is unavoidable during the RO process. It may cause adverse impacts on the environment or require high costs for treatment [49]. Therefore the treatment of RO brine is a global challenge for enhancing the overall water recovery rate [50] and thus, RO-CDI hybrid systems treating the RO brine by CDI process was proposed [51].

The simplified flow diagram of conventional two stage RO and RO-CDI stage systems is presented in Fig. 4. In the RO-CDI stage system (Fig. 4(b)), the RO brine is fed to the CDI instead of another RO process. When treating the municipal wastewater with high organic matter concentration, pretreatment was adopted before CDI process (Fig. 4(c)).

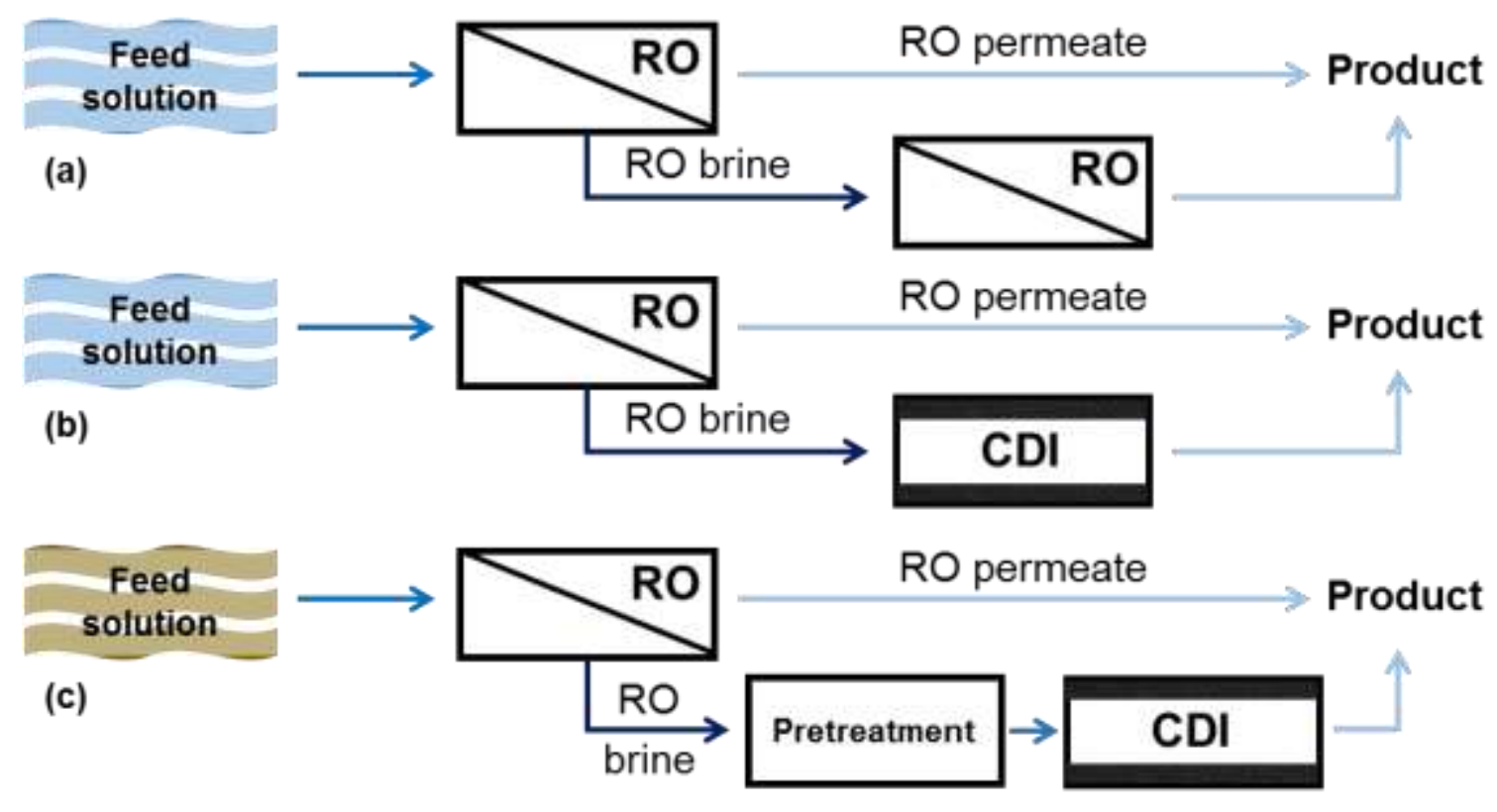

Figure 4 Schematic diagrams of RO-CDI stage systems (a) conventional two-stage RO system, (b) RO-CDI stage system for brackish water treatment, and (c) RO-CDI stage system for wastewater reclamation system. Biological activated carbon (BAC), microfiltration (MF), ultrafiltration (UF), $\mathrm{pH}$ adjustment, ozone, and sodium bisulfite were applied for pretreatment to remove organic matters before CDI process [52]. 
RO-CDI stage system was proposed for treating the industrial wastewater with 1,146 mg/L TDS concentration for water recovery increment [53]. The simulated results based on the advanced researches concluded that the CDI produced the permeate water quality as $497 \mathrm{mg} / \mathrm{L}$ when the RO brine was $1,686 \mathrm{mg} / \mathrm{L}$, satisfying the drinking water regulation from World Health Organization (WHO). Here, RO brine was the feed solution to the CDI system. Furthermore, the energy consumption of RO-CDI stage system was about $19 \%$ decreased compared to the two-stage RO system depending on the energy recovery device efficiency [53]. Energy consumption of conventional two stage RO and RO-CDI stage system were briefly summarized in Table 2. Although the reported performances of RO-CDI stage system were simulated, verification with the experimental data was clearly conducted, which convinced the successful application of RO-CDI stage system for industrial wastewater treatment.

Table 2 Specific energy consumption of two stage RO and RO-CDI stage system for treating the industrial wastewater. The feed water to the second stage process was the brine from RO process and the TDS concentration was $1,686 \mathrm{mg} / \mathrm{L}$.

\begin{tabular}{lll}
\hline System configuration & Pump efficiency $(\%)$ & SEC $\left(\mathbf{k W h} / \mathbf{m}^{\mathbf{3}}\right)$ \\
\hline \multirow{2}{*}{ Two stage RO system } & 80 & 0.184 \\
\cline { 2 - 3 } & 100 & 0.414 \\
\hline \multirow{2}{*}{ RO-CDI system } & 80 & 0.149 \\
\cline { 2 - 3 } & 100 & 0.335 \\
\hline
\end{tabular}

In addition to the industrial wastewater treatment, the application of RO-CDI stage system extends its application to the domestic wastewater reclamation even in some major cities such as Barcelona, Tokyo, and Singapore [54]. Specifically in Singapore, NEWater project was developed to increase the feasibility and viability of using reclaimed water as a water source 
for freshwater supply. As the feed water to NEWater project is the municipal wastewater, RO brine from water reclamation facility contains extremely high organic concentration (TOC: $15.0-31.1 \mathrm{mg} / \mathrm{L}$ ). As the organic matters in the feed solution cause a severe fouling in the CDI cell, several pretreatments (i.e., biological activated carbon (BAC), microfiltration (MF), ultrafiltration (UF), $\mathrm{pH}$ adjustment, ozone, or sodium bisulfite) for removing substantial amount of organic matter were applied before CDI process. The inorganic matter removal efficiency of CDI process was from 86 to $92 \%$ for the water recovery from 78 to $89 \%$. Furthermore, the overall water recovery of RO-CDI stage system was over $90 \%$ with about $15 \%$ lower energy consumption compared to the conventional two-stage RO system even considering the energy consumption for BAC [52]. Here, SEC of the pilot-scale CDI process with BAC pretreatment was $0.85 \mathrm{kWh} / \mathrm{m}^{3}$.

Even though the RO-CDI stage system exhibited the improved removal efficiency and water recovery rate, it was found that the tested pretreatment processes were not enough to remove the organics in the RO brine and thus, organic fouling was still the major problem in the CDI system. Furthermore, the energy consumption of CDI process was only evaluated, not for the entire system including pretreatment processes and RO process. Therefore, for sustainable CDI hybrid system operation, effective organic fouling control as well as fouling cleaning methods for CDI process should be further developed in addition to the system improvement.

\section{Water softening}

Water hardness due to presence of minerals such as calcium and magnesium ions causes serious problems for boilers and heat exchangers due to scale formation. Several processes have been adopted to reduce water hardness such as chemical precipitation, ion exchange 
processes, NF, RO, and ED [55]. However, most of these unit operations either consume high energy or require excessive chemicals usage, or generate a significant scaling on the surface of the membranes. Therefore, CDI has been examined as a new softening process because the CDI is operated by the electrical potential difference. Stronger attraction between the electrodes and multivalent ions convinces the feasibility of the CDI technology to be applied for the water softening. As such, the advanced researches investigated the feasibility of the CDI technology on the water softening application. (Table 3) [55-58]. 
Table 3 Removal efficiency of hardness depending on the CDI types and electrodes under various operating conditions (i.e., applied voltage and flow rate).

\begin{tabular}{|c|c|c|c|c|c|c|c|}
\hline $\begin{array}{l}\text { Hardness ion/ } \\
\text { concentration }\end{array}$ & $\begin{array}{l}\text { Applied } \\
\text { voltage } \\
\text { (V) }\end{array}$ & $\begin{array}{l}\text { Flow rate } \\
(\mathrm{mL} / \mathrm{min})\end{array}$ & $\begin{array}{l}\text { Removal } \\
\text { efficiency }\end{array}$ & \multicolumn{2}{|c|}{ CDI type/electrode } & Remarks & Ref. \\
\hline $\begin{array}{l}350 \mathrm{mg} / \mathrm{L} \text { as } \\
\mathrm{CaCO}_{3}\end{array}$ & 1.5 & 4 & $73 \%$ & \multicolumn{2}{|c|}{ CDI with carbon cloth electrode } & $\begin{array}{l}\text { Application of CDI in hardness removal using different types } \\
\text { of activated carbon electrodes }\end{array}$ & {$[55]$} \\
\hline $10 \mathrm{mM}, \mathrm{CaCl}_{2}$ & \multirow{2}{*}{1.2} & 2 & $\begin{array}{l}14.2 \mathrm{mg} \\
\mathrm{Ca}^{2+} / \mathrm{g}\end{array}$ & \multicolumn{2}{|c|}{$\begin{array}{l}\text { Ca-alginate coated on carbon } \\
\text { electrode }\end{array}$} & \multirow{2}{*}{ Application of Ca-alginate coated MCDI for hardness control } & \multirow{2}{*}{ [59] } \\
\hline $10 \mathrm{mM}, \mathrm{CaCl}_{2}$ & & 2 & $\begin{array}{l}9.8 \mathrm{mg} \\
\mathrm{Ca}^{2+} / \mathrm{g}\end{array}$ & \multicolumn{2}{|c|}{ CDI with carbon electrode } & & \\
\hline $\begin{array}{l}35 \mathrm{mg} / \mathrm{L} \text { as } \\
\mathrm{CaCO}_{3}\end{array}$ & 2 & 10 & $\begin{array}{c}3.5 \mathrm{mg} \\
\mathrm{CaCO}_{3} / \mathrm{g}\end{array}$ & \multicolumn{2}{|c|}{$\begin{array}{l}\text { CDI with purified reduced } \\
\text { graphene oxide electrode }\end{array}$} & $\begin{array}{l}\text { Ultra-pure graphene oxide and reduced graphene oxide } \\
\text { electrode for hardness control }\end{array}$ & {$[60]$} \\
\hline $266 \mathrm{mg} / \mathrm{L}, \mathrm{CaCl}_{2}$ & 2 & 20 & $90 \%$ & \multicolumn{2}{|c|}{$\begin{array}{l}\text { CDI with activated carbon cloth } \\
\text { electrode }\end{array}$} & Fabrication of carbon cloth electrode for hardness removal & [61] \\
\hline $\begin{array}{c}46 \mathrm{mg} / \mathrm{L}, \mathrm{Ca}^{2+} \\
5.1 \mathrm{mg} / \mathrm{L}, \mathrm{Mg}^{2+}\end{array}$ & 1.2 & $\begin{array}{l}28,000 \\
28,000\end{array}$ & $\begin{array}{l}74 \% \\
71 \%\end{array}$ & \multicolumn{2}{|c|}{$\begin{array}{l}\text { MCDI with porous carbon } \\
\text { electrode }\end{array}$} & $\begin{array}{l}\text { Application of MCDI for cooling tower feed water } \\
\text { desalination }\end{array}$ & [37] \\
\hline $1.45 \mathrm{mM}, \mathrm{Ca}^{2+}$ & \multirow{2}{*}{2} & 10 & $58 \%$ & \multirow{2}{*}{\multicolumn{2}{|c|}{$\begin{array}{l}\text { CDI with activated carbon } \\
\text { electrode in a multi-ionic } \\
\text { environment }\end{array}$}} & \multirow{2}{*}{ Ion selectivity study using CDI in a multi-ionic environment } & \multirow{2}{*}{ [62] } \\
\hline $2.41 \mathrm{mM}, \mathrm{Mg}^{2+}$ & & 10 & $47 \%$ & & & & \\
\hline $2.5 \mathrm{mM}, \mathrm{CaCl}_{2}$ & 1.5 & - & \begin{tabular}{l|}
$98 \%$ \\
$\sim 89 \%$ \\
$16 \%$ \\
$\sim 82 \%$ \\
\end{tabular} & $\begin{array}{l}\text { CDI with } \\
\mathrm{SiO}_{2} \text { coating } \\
\text { carbon } \\
\text { electrodes }\end{array}$ & $\begin{array}{c}\text { Carbon foam } \\
\text { Carbon nanofoam } \\
\text { Carbon cloth } \\
\text { Carbon sheet } \\
\end{array}$ & $\begin{array}{l}\text { Removal efficiency of CDI depending on carbon materials and } \\
\text { the effect of coating on the surface of the electrodes }\end{array}$ & [63] \\
\hline $3 \mathrm{mM}, \mathrm{CaSO}_{4}$ & 0.8 & 110 & $\begin{array}{l}1.35 \mathrm{mg}, \\
\mathrm{CaSO}_{4} / \mathrm{g} \\
2.97 \mathrm{mg}, \\
\mathrm{CaSO}_{4} / \mathrm{g} \\
4.38 \mathrm{mg}, \\
\mathrm{CaSO}_{4} / \mathrm{g} \\
3.38 \mathrm{mg} \\
\mathrm{CaSO}_{4} / \mathrm{g} \\
\end{array}$ & \multicolumn{2}{|c|}{$\begin{array}{l}\text { CDI with } \mathrm{SiO}_{2} \text { coating carbon } \\
\text { electrodes }\end{array}$} & $\begin{array}{l}\text { Effect of applied voltage and flow rate on the ion } \\
\text { removal/regeneration, charge efficiency and energy } \\
\text { consumption }\end{array}$ & {$[64]$} \\
\hline
\end{tabular}


Specifically, novel CDI electrodes for water softening have been aggressively developed. The removal of calcium ions was $44 \%$ higher with Ca-alginate coated electrode compared to conventional CDI due to increased charge efficiency (55\% for CDI against $85 \%$ for Caalginate-CDI (CA-CDI)) [59]. Another coating material, nanoporous $\gamma-\mathrm{Al}_{2} \mathrm{O}_{3}$ or $\mathrm{SiO}_{2}$ was coated on Porvair carbon for increasing the $\mathrm{Ca}^{2+}$ removal efficiency $[65,66]$. With the coating on the surface of the carbon electrodes, specific surface area as well as the electrochemical properties of the electrodes was improved and the quantity of the removed $\mathrm{Ca}^{2+}$ was between four and five times higher than the uncoated electrodes. Coating material significantly influenced the $\mathrm{Ca}^{2+}$ removal efficiency, however, carbon material also takes great importance on the removal efficiency. When $\mathrm{SiO}_{2}$ was coated on the carbon foam and/or nanofoam exhibited great removal efficiency (about 89-98\%), on the other hands, the removal efficiency of the carbon cloth with $\mathrm{SiO}_{2}$ coating was only $16 \%$ [63]. It should be also noted that applied voltage and flow rate directly determine the removal efficiency. Increasing voltage and flow rate resulted in increased removal efficiency [64].

In addition, a higher removal for calcium ions was reported for carbon cloth over composite electrode due to better wettability of the carbon cloth [55]. The authors also noted the importance of optimizing the pore size of the electrodes to improve the ion selectivity for divalent ions for possible water softening applications [67]. The interesting approach for hardness removal using ion exchange process under CDI was also reported by adopting zeolite modified carbon electrode for hardness removal through CDI-assisted ion exchange mechanism [68]. The application of external voltage led to remarkable increase in calcium removal. In a slightly different study, a novel concept was introduced, where a monovalent cation selective membrane was used in MCDI to produce divalent cation-rich solution as a means to stabilize permeate from NF or low pressure RO (LPRO) [69]. This is another example where MCDI can be innovatively configured to serve specific needs for different applications. 
CDI has distinct advantages in water softening mainly for its low energy consumption as well as chemical-free process and because of that, Dutch company Voltea already supplies modular based CDI units for water softening. Although a previous research reported that there was little concern on the scaling problem in CDI technology [70], however, scaling on the spacer or the presence of ferric ion may deteriorate the product water quality. For that reasons, further investigation for sustainable operation of CDI on pilot or real scale plant could help meet overall system optimization which could be followed by the improved performance.

\section{Selective removal}

In recent years, the selective removal of specific ions from the feed solution has become critical issues in many industrial processes such as valuable resources recovery or toxic ion removal $[1,71,72]$. As a result, there are lots of innovations in technologies, however, generation of the secondary waste stream, higher energy consumption and higher capital cost were noted to be the inherent challenges $[73,74]$. Therefore, the feasibility of CDI process for selective removal has been extensively explored in this section.

\subsection{Heavy metal removal}

Due to rapid industrial development, increasing amount of toxic heavy metals such as lead, cadmium, chromium etc. are released into the environment. A comprehensive review on the existing technologies for heavy metal removal was conducted [74]. The most common heavy metal removal technologies include chemical precipitation, ion-exchange, adsorption, membrane processes, coagulation and flocculation, and electrochemical processes. The review found certain disadvantages of the above processes. For example, chemical precipitation produces large volume of sludge and secondary waste, and they are good only for water 
containing high concentration of ions. Similarly, ion-exchange also generates secondary waste during regeneration of resin, and they have limited large-scale applicability. Pressure driven membrane processes are known to be efficient in heavy metal removal but they have higher operating cost, and electrochemical processes have higher energy and capital cost. Since CDI is proven to be an energy efficient technology for low TDS water, and it does not use any chemical in the processes, it can be a viable technology for heavy metal removal.

There are several studies on CDI application in removing different species of heavy metals from various water sources (Table 4). Removal efficiency difference between lead and sodium was critically investigated depending on the $\mathrm{pH}$, initial lead concentration, and time [75]. Lead was more sensitively affected by the $\mathrm{pH}$ changes and the removal efficiency was highest at the neutral $\mathrm{pH}$ condition ( $\mathrm{pH}$ was 6). Another interesting results were the adsorption rate of lead and sodium. Due to the relatively high charge of lead compared to sodium, the adsorption equilibrium of lead was reached in a very short time, which indicates that highest removal selectivity between lead and sodium could be achieved with relatively lower operating time and neutral $\mathrm{pH}$ condition.

In addition to the study on lead removal, fundamental research on the removal efficiency of the two kinds of arsenic $(\mathrm{As}(\mathrm{V})$ and $\mathrm{As}(\mathrm{II}))$ was also studied with different initial concentration of arsenic and applied voltage on the CDI system [76]. As expected, increased applied voltage and initial arsenic concentration resulted in the increased removal efficiency of both $\operatorname{As}(\mathrm{V})$ and $\operatorname{As}($ III). However, the sorption capacity of $\operatorname{As}(\mathrm{V})$ was higher than that of $\operatorname{As}($ III) under all of the operating conditions. Additionally, with the presence of $\mathrm{NaCl}$ or natural organic matter (NOM), removal efficiency of both arsenic ions were declined due to the competition effect. Specifically, NOM could potentially obstruct the electrode pores and therefore, specific surface area was decreased. 
As the CDI process is operated with the potential difference between the pairs of the electrodes, charge and hydrated radius of the ions in the water determine the removal efficiency. Therefore, when considering the individual removal test, although cadmium and lead exhibits identical charge valence, due to the relatively large hydrated radius of the cadmium (4.26 and $4.01 \AA$ of cadmium and lead, respectively), lead was more favorable removed. However, it should be noted that despite the larger hydrated radius of chromium than that of cadmium or lead, removal efficiency of the chromium was much higher [77]. Similar removal efficiency trend was observed when three metals were mixed in the solution with same concentration. Specifically, the removal efficiency of cadmium was significantly inhibited due to the combined effect of hydraulic radius and charge valance [73]. 
Table 4 Removal efficiency of heavy metal ions by CDI.

\begin{tabular}{|c|c|c|c|c|c|}
\hline Pollutants & Concentration & Electrodes & Removal efficiency & Remarks & Ref. \\
\hline \multirow{4}{*}{ Arsenic } & $0.02-0.1 \mathrm{mg} / \mathrm{L}$ & $\begin{array}{l}\text { Activated } \\
\text { carbon }\end{array}$ & $86-98 \%$ & $\begin{array}{l}\text { Use of solar-powered CDI unit for arsenic removal from synthetic } \\
\text { water }\end{array}$ & [78] \\
\hline & \multirow{2}{*}{$0.1-200 \mathrm{mg} / \mathrm{L}$} & \multirow{2}{*}{$\begin{array}{l}\text { Activated } \\
\text { carbon }\end{array}$} & $0.01-0.025 \mathrm{mg}, \mathrm{As}(\mathrm{V}) / \mathrm{g}$ & \multirow{2}{*}{$\begin{array}{l}\text { Effect of applied voltage and initial concentration on the removal } \\
\text { efficiency of } \operatorname{As}(\mathrm{V}) \text { and } \operatorname{As}(\text { III })\end{array}$} & \multirow{2}{*}{ [76] } \\
\hline & & & $0.005-0.014 \mathrm{mg}, \mathrm{As}(\mathrm{II}) / \mathrm{g}$ & & \\
\hline & $0.2 \mathrm{mg} / \mathrm{L}$ & \multirow{2}{*}{$\begin{array}{l}\text { Activated } \\
\text { carbon }\end{array}$} & $98.51 \%$ & \multirow{2}{*}{$\begin{array}{l}\text { Practical application of commercial CDI module for arsenic and lead } \\
\text { removal in Mexico }\end{array}$} & \multirow{2}{*}{ [79] } \\
\hline \multirow{3}{*}{ Lead } & $0.0267 \mathrm{mg} / \mathrm{L}$ & & $>60 \%$ & & \\
\hline & $5-100 \mathrm{mg} / \mathrm{L}$ & $\begin{array}{l}3 \mathrm{D} \\
\text { graphene }\end{array}$ & $60-99 \%$ & $\begin{array}{l}\text { Heavy metal separation from wastewater by } \mathrm{CDI} \text { with } 3 \mathrm{D} \text { graphene- } \\
\text { based asymmetric electrodes depending on } \mathrm{pH} \text {, voltage, and }\end{array}$ & [75] \\
\hline & $0.5 \mathrm{mM}$ & \multirow{3}{*}{$\begin{array}{l}\text { Activated } \\
\text { carbon }\end{array}$} & $43 \%$ & \multirow{3}{*}{$\begin{array}{l}\text { Assessment of CDI application in heavy metal (i.e., lead, cadmium, } \\
\text { and chromium) removal }\end{array}$} & \multirow{3}{*}{ [77] } \\
\hline Cadmium & $0.5 \mathrm{mM}$ & & $32 \%$ & & \\
\hline \multirow{4}{*}{ Chromium } & $0.5 \mathrm{mM}$ & & $52 \%$ & & \\
\hline & $2 \mathrm{mg} / \mathrm{L}$ & $\begin{array}{l}\text { Carbon } \\
\text { aerogel }\end{array}$ & $99.6 \%$ & $\begin{array}{l}\text { Application of CDI in removal of chromium from wastewater using } \\
\text { carbon aerogel electrode }\end{array}$ & [73] \\
\hline & $0.035 \mathrm{mg} / \mathrm{L}$ & \multirow{2}{*}{$\begin{array}{l}\text { Carbon } \\
\text { aerogel }\end{array}$} & $94 \%$ & \multirow{2}{*}{$\begin{array}{l}\text { Chromium ions removal using carbon aerogel electrodes for ground } \\
\text { water remediation }\end{array}$} & \multirow{2}{*}[80]{} \\
\hline & $0.025 \mathrm{mg} / \mathrm{L}$ & & $88 \%$ & & \\
\hline Copper & $50 \mathrm{mg} / \mathrm{L}$ & $\begin{array}{l}\text { Activated } \\
\text { carbon }\end{array}$ & $>90 \%$ & Copper ions removal from aqueous solution with CDI & [81] \\
\hline
\end{tabular}




\subsection{Phosphate and nitrate removal}

Similarly to heavy metal species, high concentration of phosphates and nitrates contained in the wastewater from agriculture and industrial applications should be removed for preventing the environmental concerns such as eutrophication of water source $[82,83]$. While phosphorus is an environmental pollutant, it is also an essential element for food production, which is in short supply, therefore, it is not only important to treat water for phosphorus removal but it also has to be recovered [84]. The common unit process for phosphorus removal and recovery from wastewater is the struvite precipitation and sludge incineration where $\mathrm{P}$ recovery between $90-98 \%$ and $75 \%$ respectively can be achieved but it has substantial investment due to high chemical and energy demand [84, 85].

Furthermore, full-scale technologies are already applied for nitrate removal [86], where maximum nitrate removal efficiency reported was $100 \%$ for biological process followed by membrane process such as RO (97\%), ion-exchange (90\%) and chemical process (70\%). While the removal efficiencies have been reported to be quite good, there still remains the issues of operational cost, requirement of pre-treatment and post-treatment, and generation of secondary pollution as some of the challenges of these technologies. Therefore, several studies evaluated the removal efficiency of the phosphate and nitrate by the CDI process.

A pilot CDI unit (AQUA, EWP) was tested to evaluate phosphate removal and the removal efficiencies were $86 \%$ and $77 \%$ for feed water containing 50 and $300 \mathrm{mg} / \mathrm{L}$ phosphate, respectively [87]. They also observed lower removal efficiencies for higher initial phosphate concentration and higher flow rates with optimum pH between 5 and 6, achieving $98 \%$ removal with a three staged system. Another study also utilized same CDI unit for investigating the removal efficiency of nitrate at different initial nitrate $(100,300$, and $500 \mathrm{mg} / \mathrm{L}$ of nitrate with $2.0 \mathrm{~g} / \mathrm{L}, \mathrm{NaCl})$ and $\mathrm{NaCl}(300 \mathrm{mg} / \mathrm{L}$ of nitrate with $1.5,2.0$, and $3.0 \mathrm{~g} / \mathrm{L}, \mathrm{NaCl})$ concentration, respectively [88]. Although the experimental data was obtained from the batch mode CDI 
system operation, developed transport model was in good agreement with the tested results. Based on the model, removal trends of more diverse ion species could be further investigated. Likewise, a commercial CDI unit (DesEL Technology, ENPAR Tech. Inc.) was also used to assess nitrate removal from wastewater (88-98\%, removal rate) [89].

In the separate study, the removal efficiency and selectivity of nitrate was significantly improved with the coated anion-exchange resin (BHP 55) with high nitrate selectivity [90, 91]. The resin employed in both studies preferably adsorbs nitrate ions than the other anions. Similar to BHP 55 coating, asymmetric carbon electrodes coated with $\mathrm{SiO}_{2}$ and $\mathrm{Al}_{2} \mathrm{O}_{3}{ }^{-}$were employed and higher nitrate removal capacity was observed compared to the uncoated symmetric carbon electrodes [92]. It could be explained by the faster ion transport due to the reduced hydrophobicity, increased specific surface area, and increased adsorption sites. Aforementioned studies improved the nitrate removal efficiency with coating on the surface of the carbon electrodes, on the other hands, a novel CDI electrode (Pd/NiAl-LMO film electrode) was newly developed [93]. Pd/NiAl-LMO electrode effectively capture nitrate and convert nitrate to nitrogen $\left(\mathrm{N}_{2}\right)$ through the regeneration period.

Removal selectivity of CDI is governed by the characteristics of feed contaminant (i.e., ionic charge, hydrated radius, and initial concentration of ions), operating conditions (i.e., applied voltage), and electrode properties (i.e., pore size, pore size distribution, and structure) $[62,73,77,94]$. Therefore, comprehensive understanding for the factors influencing the removal selectivity is required and the electrode with optimized pore size and distribution should be further developed for the better removal selectivity. 


\section{Energy efficiency improvement}

Due to the intensive energy consumption of conventional desalination techniques, CDI has emerged as the new technology for energy and cost effective desalination process. However, there still exists tremendous potential for reducing or recovering the energy. With further improvement of energy efficiency, CDI can be more cost competitive and broaden its applications. There are two primary strategies to enhance the energy efficiency of CDI: (1) energy recovery of CDI process during the desorption period and (2) hybridization of CDI with energy producing process.

\subsection{Energy recovery of MCDI process}

There have been great efforts on improving the energy efficiency of the MCDI technology and the energy recovery during the desorption stage [95-99]. The adsorbed ions in the electrical double layers move from the electrode into the feed stream and the electrons were transported over the external load simultaneously, which resulted in the energy recovery [36]. As summarized in Table 5, with the introduction of nanoporous activated carbon electrode, 30 to $45 \%$ of the consumed energy could be recovered [100], while under the optimized operating condition, up to $83.2 \%$ of energy recovery can be achieved. Indeed, the energy recovery rate can be more than $70 \%$ with inexpensive hydrophilic activated-charcoal based electrodes [101]. It was also argued that the energy recovery reached $40 \%$ for the conventional CDI cell [98]. Moreover, up to $83 \%$ of the used energy can be recovered in the regeneration phase under constant current condition using a membrane CDI stack [36]. Energy recovery was tested under two major operating conditions, constant voltage $(\mathrm{CV})$ and constant current mode (CC). In order to identify optimum operating mode for higher energy recovery, energy recovery was tested under different voltages and currents for CV and CC mode, respectively [102]. From the 
results, $\mathrm{CC}$ mode operation was found to be more advantageous than $\mathrm{CV}$ mode due to the higher energy storage.

The energy recovery ratio of various operating conditions (operating time, feed solution salinity, and charging current) and system configuration of CDI (cell size and electrode surface) were also investigated $[98,103]$. The energy recovery ratio of the CDI system increased with the increment of feed solution salinity, applied voltage, but decrement of the cycle duration. Specifically, optimum electrode surface and current for minimizing the energy losses was critically simulated and validated $[103,104]$. On the other hand, the size of the CDI system has little impact on the energy recovery ratio although increased system size may enhance the thermodynamic efficiency. 
Table 5 Recent improvements on energy recovery of the CDI process. CC and CV respectively indicates constant current and constant voltage.

\begin{tabular}{|c|c|c|c|c|c|c|c|}
\hline \multirow{2}{*}{$\begin{array}{c}\text { Maximum } \\
\text { energy } \\
\text { recovery }(\%)\end{array}$} & \multirow{2}{*}{$\begin{array}{l}\text { CDI } \\
\text { type }\end{array}$} & \multicolumn{5}{|c|}{ Experimental conditions } & \multirow[b]{2}{*}{ Ref. } \\
\hline & & Electrodes & $\begin{array}{l}\text { Recovery } \\
\text { mode }\end{array}$ & $\begin{array}{l}\text { Feed solution } \\
\text { concentration }\end{array}$ & $\begin{array}{l}\text { Applied current for } \\
\text { desorption }\end{array}$ & Remarks & \\
\hline 83 & MCDI & $\begin{array}{l}\text { Activated } \\
\text { carbon }\end{array}$ & $\begin{array}{l}\mathrm{CC} \\
\text { mode }\end{array}$ & $8.6-86 \mathrm{mM}$ & $2-15 A$ & $\begin{array}{l}\text { Energy recovery of MCDI depending on the } \\
\text { feed solution quality and applied current }\end{array}$ & [36] \\
\hline 40 & MCDI & $\begin{array}{l}\text { Activated } \\
\text { carbon }\end{array}$ & $\begin{array}{l}\mathrm{CC} \\
\text { mode }\end{array}$ & $20 \mathrm{mM}$ & $8.64 \mathrm{~mA}$ & $\begin{array}{l}\text { Energy recovery in MCDI and CDI under CC } \\
\text { and } \mathrm{CV} \text { mode }\end{array}$ & [96] \\
\hline 20 & FCDI & $\begin{array}{l}\text { Activated } \\
\text { carbon }\end{array}$ & $\begin{array}{c}\mathrm{CC} \\
\text { mode }\end{array}$ & $35 \mathrm{~g} / \mathrm{L}$ & $0.1 \mathrm{~A}$ & Performance and energy recovery in FCDI & [97] \\
\hline $\begin{array}{l}29 \\
39 \\
63\end{array}$ & $\mathrm{CDI}$ & Carbon aerogel & $\begin{array}{l}\mathrm{CV} \\
\text { mode }\end{array}$ & $\begin{array}{l}0.5 \mathrm{~g} / \mathrm{L} \\
1.0 \mathrm{~g} / \mathrm{L} \\
1.5 \mathrm{~g} / \mathrm{L}\end{array}$ & $1 \mathrm{~mA}$ & $\begin{array}{l}\text { Effect of operating time, feed solution } \\
\text { concentrations, and CDI system sizes on energy } \\
\text { recovery in CDI }\end{array}$ & [98] \\
\hline 83 & MCDI & $\begin{array}{l}\text { Activated } \\
\text { carbon }\end{array}$ & $\begin{array}{c}\mathrm{CC} \\
\text { mode }\end{array}$ & $0.5-1 \mathrm{~g} / \mathrm{L}$ & $1 \mathrm{~A}$ & $\begin{array}{l}\text { Effect of water recovery and flow rate on energy } \\
\text { recovery in MCDI }\end{array}$ & [105] \\
\hline
\end{tabular}


The increasing attention to the water-energy nexus encourages the development of technologies that efficiently remove the contaminants during water treatment as well as energy production from the water resources [106]. In this respect, the energy efficiency of CDI process is expected to be greatly improved by integrating with energy producing processes such as (1) RED and (2) MFC as illustrated in Fig. 5.
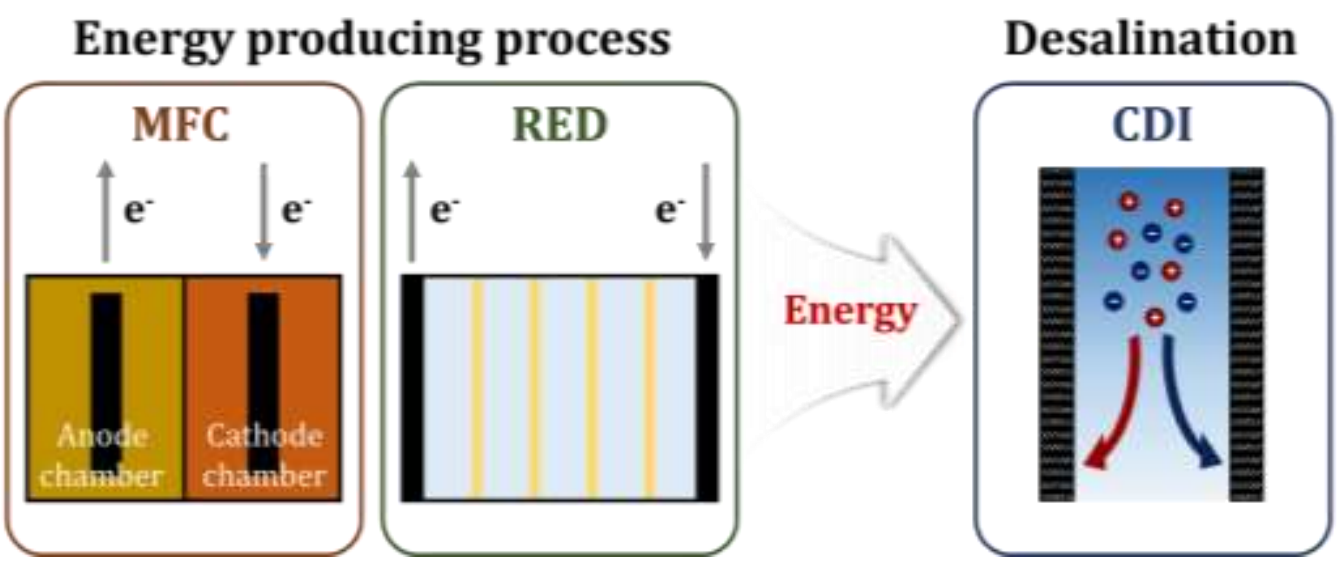

Figure 5 Schematic diagram of the CDI based integration system with the energy producing process (e.g., MFC and RED process). Harnessed energy by the MFC and RED process was utilized as the driving for of the CDI process.

\subsubsection{CDI-RED hybrid system}

RED, one of the emerging membrane-based technologies for producing energy from salinity gradient, has received attention these days. In a RED system, the chemical potential difference causes the transport of ions through the membranes from the concentrated solution to the diluted solution and therefore, electrical power can be sustainably generated [107].

The CDI-RED hybrid system has been investigated for decreasing the energy consumption of CDI operation by utilizing the inevitable waste brine as the electric energy resource [108, 109]. The feed solution is initially fed to the CDI cell and the outlet of the CDI system is divided 
into four parts: fresh water, high concentration solution, low concentration solution, and the brine. Among them, high and low concentration solution were injected to RED system for energy production. Therefore, desalinated water and electric power can be produced at the same time by this hybrid system. The modeled result exhibited that the UPW $(0.0001 \mathrm{mg} / \mathrm{L})$ and fresh water $(5.67 \mathrm{mg} / \mathrm{L})$ were effectively produced with $46.5 \%$ decreased energy consumption compared to the simple CDI system.

\subsubsection{CDI-MFC hybrid system}

MFC has been developed to be a promising technology that enables both electricity generation and wastewater treatment with a single device [110]. MFC converts biochemical potential of the organic compounds to electrical energy through exoelectrogenic bacteria and thus, electricity is directly produced. However, the low quantity of the power generated by MFC hindered the direct applications of MFC [111].

In contrast with other electrochemical processes such as ED, CDI is operated at relatively low voltages and thus, the CDI-MFC hybrid systems were proposed for wastewater treatment and saline water desalination simultaneously without any energy input [112]. Typically, the CDI-MFC hybrid system is composed of two parallel processes: (1) MFC for wastewater treatment as well as electric power generation and (2) CDI for brackish water desalination (Fig. 6 (a)). The anode and cathode electrodes of MFC are directly connected with the activated carbon electrodes of CDI and the potential gradient generated in MFC system drives the ion transfer in the electrical field of CDI for brackish water deionization. 

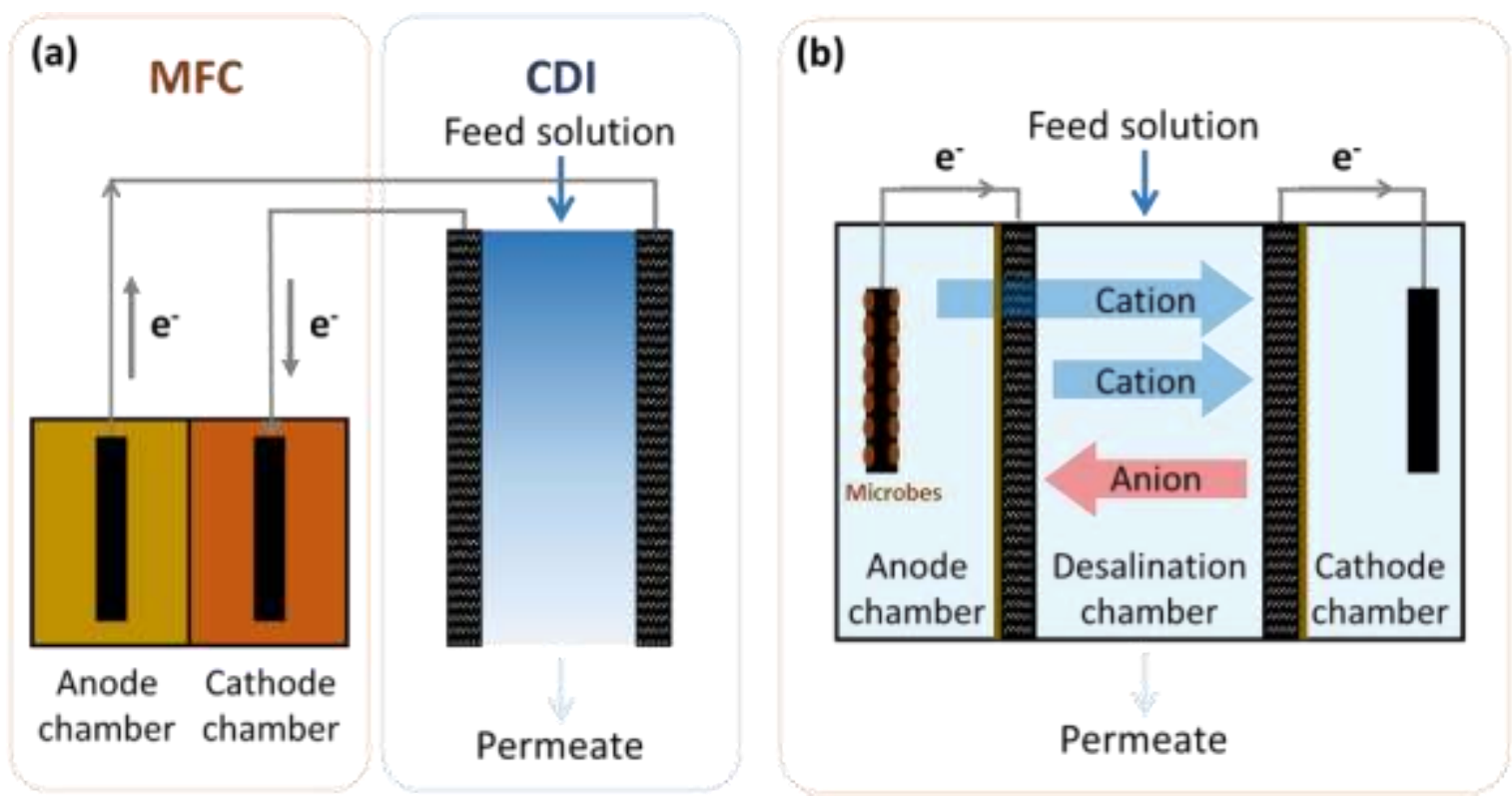

Figure 6 Schematic diagram of (a) CDI-MFC hybrid system and (b) MCDC system. The desalination chamber separated with anode and cathode chamber with two different assemblies. Cation exchange membrane is installed on the anode and cathode side assembly for preventing microbial growth.

The competent desalination efficiency of CDI process $(73.0-79.2 \%)$ was observed when MFC supplied power to CDI [113]. Three different connections types of MFC to supply electrical potential to the CDI system: single MFC, MFCs in series, and MFCs in parallel were tested [112]. Three systems showed a similar trend of output voltage and removal efficiency of CDI system. Among them, parallel system exhibited highest performance, however, the lowest performance of the series system was observed due to the effectiveness of the electrons transfer leading to higher current in the system.

Furthermore, microbial desalination cells (MDCs), one of advanced MFC is emerged as a promising technology to simultaneously treat saline water and produce renewable energy [114]. On contrary to conventional MFC, the additional desalination function can be achieved in an MDC by adding a middle chamber containing saline water. Moreover, the anode-cathode 
potential difference drives the migration of anions to the anode chamber and cations to the cathode chamber for charge neutrality [115]. In order to utilize the mutual benefits between the MDC and CDI, microbial capacitive desalination cell (MCDC), integrating MDC with the concept of CDI was investigated (Fig. 5 (b)) [116-118]. In MCDC system, saline water can be desalinated through electrical potential over the activated carbon driven by the microorganisms.

The average salt removal efficiency of the CDI (desalination chamber in MCDC system) during one cycle was $69.4 \%$ with $10 \mathrm{~g} / \mathrm{L} \mathrm{NaCl}$ feed solution [116]. In addition, to optimize the system configuration, several types of MCDC system were tested. When the feed water TDS was $1,000 \mathrm{mg} / \mathrm{L}$, the removal rate of CDI was $61.2,59.4$, and $74.7 \%$ with single-, series, and parallel-configuration of MCDC system, respectively [116]. As shown in the CDI-MFC hybrid system, paralleled MDCs as the power supply to CDI exhibited the highest desalination performance due to larger amount of electrical potential generated from MDCs. Besides, the salt removal efficiency of the MCDI decreased with the increased operating time from 35.5 to $12.0 \%$.

Several previous researches indicated that CDI could be competitive to RO in terms of energy efficiency, however, RO is generally applied for the seawater with 35,000 mg/L, TDS, not for the brackish water having the TDS concentration lower than 4,000 mg/L. This implies that there should be further improvement on the energy efficiency of CDI to overcome the conventional brackish water treatment process such as NF process. Fortunately, there have been great efforts for improving the energy efficiency of CDI process by utilizing the external elements including energy recovery during desorption period and integration with energy producing electrochemical processes. In addition to that, saving the energy consumption of the CDI process for desalination on adsorption phase and/or developing novel operating mode 
[119] is considered to be the most critical. Therefore, guideline for optimization of the operating conditions, CDI module design, and novel electrode development may promise the commercialization of CDI process in various application areas.

\section{Challenges in CDI technology: fouling, scaling, and scale-up}

With expanding the application of CDI, harsher water resources (e.g., seawater or municipal wastewater) have been gradually investigated as the feed solution. Although the regeneration stage of CDI process mitigates formation of fouling layer or precipitation of components from the solution onto the electrode surface [120,121], organic fouling or scaling potential still deteriorates the sustainability of CDI [7]. Specifically, fouling and/or scaling could decrease removal efficiency and permeate flow rate as well as increase energy consumption [70]. It is also noteworthy that sustainable operation of CDI is as critical as developing high removal performance electrodes or system, however, there have been only a few studies on organic fouling in CDI. For better understanding and improving the CDI sustainability, fundamental investigations of CDI on fouling/scaling mechanism should be a priority. Then, optimized pretreatment processes and cleaning methods with different feed solution properties for organic fouling control are considered to be essential. With these advances, successful and sustainable operation of CDI in the real application could be achieved.

Another limitation of recent studies on CDI technology is scale-up. There have been a few studies utilizing the pilot-scale CDI unit [122, 123], however, only the energy consumption of the CDI itself was reported. Even in a small pilot scale unit, the auxiliary energy consumption is considered to be essential to drive the cyclic operation which is unique for MCDI process: pre-charge step, charge step, discharge/cleaning step in a cycle, each step is delivered by electronically controlling the valves, and consumes extra energy. Therefore, in parallel with 
the CDI technology development, specific equipment supporting the CDI system operation should be designed.

\section{Perspectives and outlook for expanding the CDI applications}

As reviewed in this paper, there are tremendous applicable areas of the CDI technology, however, most of the researches focused only on improving the removal efficiency of the CDI processes. Developing the optimized CDI system for specific application is considered to be more essential. Table 6 critically summarizes the practical guidelines for each application of the CDI process with respect to the optimized electrode, hybrid system and operating strategy.

For UPW production, electrodes with high removal efficiency should be employed with RO-CDI pass system or CDI-RED hybrid system. When employing the RO-CDI pass system, satisfactory product water quality is expected with great energy efficiency and CDI-RED system could guarantee extremely low energy consumption. On contrary, as wastewater caused severe fouling on the electrodes or ion exchange membranes, fouling control is considered to be the main concern. Furthermore, utilization of RO-CDI stage system or CDI-MFC system can significantly increase the water recovery and energy efficiency, respectively. For water softening and selective removal, optimized pore size and pore distribution of the electrodes for the target contaminant (e.g., divalent cations, heavy metals, phosphate, or nitrate) are recommended.

Another critical issue for practical application of the CDI process could be the pilot- and/or full-scale experiments. There have been some simulated performances and energy efficiency of the CDI processes from the previous studies, however, to implement the CDI process for the full-scale demonstrations, more actual applications through the pilot- and/or full-scale plants 
should be further directed. Particularly, in addition to developing the CDI process itself, specific devices and system optimization for the successful operation of the CDI system need to be advanced. Based on our guidelines, the implementation of CDI technology is expected to be extended. 
Table 6 Practical guidelines for expanding the application of CDI process with respect to electrode material, hybrid system and operating strategy.

\begin{tabular}{|c|c|c|c|c|}
\hline Appl & ation & Electrode & Hybrid system & Operating strategy \\
\hline \multirow[b]{2}{*}{ Desalination } & UPW & $\begin{array}{l}\text { High surface area } \\
\text { High salt adsorption capacity } \\
\text { Low electrical resistivity } \\
\text { Optimized pore size distribution }\end{array}$ & RO-CDI pass & $\begin{array}{l}\text { High removal efficiency } \\
\text { High energy efficiency }\end{array}$ \\
\hline & Wastewater & $\begin{array}{l}\text { Fouling resistance electrodes/ } \\
\text { ion exchange membranes } \\
\text { High surface area/salt adsorption } \\
\text { Selective nutrients electroadsorption } \\
\text { capacity }\end{array}$ & RO-CDI stage & $\begin{array}{l}\text { High water recovery } \\
\text { Fouling control }\end{array}$ \\
\hline Water softening & & $\begin{array}{l}\text { High wettability } \\
\text { Optimized pore size to divalent cations }\end{array}$ & - & $\begin{array}{l}\text { High removal efficiency } \\
\text { Scaling control }\end{array}$ \\
\hline Selective removal & $\begin{array}{l}\text { Heavy metal } \\
\text { Phosphate/nitrate }\end{array}$ & Optimized pore/ pore size distribution & - & $\begin{array}{l}\text { Interaction between } \\
\text { charged ions }\end{array}$ \\
\hline
\end{tabular}




\section{Concluding remarks}

Although CDI is still an emerging technology, it is increasingly investigated as the nextgeneration water desalination process due to its competent removal, energy efficiency, and removal selectivity. The application potential for CDI seems promising and this review paper quantitatively estimates the feasibility of CDI and suggest the guidelines for various applicable areas. Major applicable areas and challenges of CDI are summarized as follows:

- Recent developments on novel electrodes of CDI technology encourage its application on brackish water treatment. Furthermore, RO-CDI hybrid system is expected to have significant potential for UPW production as well as wastewater treatment with great energy efficiency and sufficient removal efficiency.

- Removal selectivity of CDI has been reported to be the promising solution for water softening, heavy metal, and phosphate/nitrate removal. Most of the charged species were satisfactorily removed, however competition between the existing ions in the feed solution and scaling problem may deteriorate the removal selectivity. Thus, further fundamental studies of the interaction between the charged ions are recommended.

- Although CDI is considered as an energy efficient technology when treating brackish water, there still remains great potential in reducing the energy consumption. Energy recovery during desorption stage and hybrid system with energy producing technology (RED) significantly improved the energy efficiency and even no energy was required for CDI-MFC hybrid system. Consequently, practical guidelines for the CDI application were proposed.

Despite of the great applicability of CDI process, the sustainability of CDI process is questionable in terms of scaling and organic fouling. A large number of pre-treatments and cleaning methods were tested, however, CDI was still suffered from the fouling, which could 
be followed by decreased charge efficiency and life span. Therefore, studies on the sustainable operation of CDI process should be carried out for further expanding the application of CDI technology.

\section{Acknowledgements}

This work is supported by the Korea Agency for Infrastructure Technology Advancement (KAIA) grant funded by the Ministry of Land, Infrastructure and Transport (Grant 18IFIPB116952-03).

\section{References}

[1] J. Choi, B.G. Choi, S. Hong, Effects of NF treated water on corrosion of pipe distribution system and its implications to blending with conventionally treated water, Desalination, 360 (2015) 138-145.

[2] R. Rautenbach, K. Voßenkaul, Pressure driven membrane processes - the answer to the need of a growing world population for quality water supply and waste water disposal, Separation and purification technology, 22 (2001) 193-208.

[3] T. Xu, C. Huang, Electrodialysis- based separation technologies: a critical review, AIChE journal, 54 (2008) 3147-3159.

[4] S. Jamaly, N. Darwish, I. Ahmed, S. Hasan, A short review on reverse osmosis pretreatment technologies, Desalination, 354 (2014) 30-38.

[5] Y. Ghalavand, M.S. Hatamipour, A. Rahimi, A review on energy consumption of desalination processes, Desalination and Water Treatment, 54 (2015) 1526-1541.

[6] S. Porada, R. Zhao, A. Van Der Wal, V. Presser, P. Biesheuvel, Review on the science and technology of water desalination by capacitive deionization, Progress in Materials Science, 58 (2013) 1388-1442.

[7] F.A. AlMarzooqi, A.A. Al Ghaferi, I. Saadat, N. Hilal, Application of capacitive deionisation in water desalination: a review, Desalination, 342 (2014) 3-15.

[8] Y.-J. Kim, J.-H. Choi, Improvement of desalination efficiency in capacitive deionization using a carbon electrode coated with an ion-exchange polymer, Water research, 44 (2010) 990996.

[9] F. Ahmad, S.J. Khan, Y. Jamal, H. Kamran, A. Ahsan, M. Ahmad, A. Khan, Desalination of brackish water using capacitive deionization (CDI) technology, Desalination and Water Treatment, 57 (2016) 7659-7666.

[10] C. Zhang, D. He, J. Ma, W. Tang, T.D. Waite, Faradaic reactions in capacitive deionization (CDI)-problems and possibilities: A review, Water research, 128 (2018) 314-330. 
[11] H. Li, L. Zou, Ion-exchange membrane capacitive deionization: a new strategy for brackish water desalination, Desalination, 275 (2011) 62-66.

[12] N.-S. Kwak, J.S. Koo, T.S. Hwang, E.M. Choi, Synthesis and electrical properties of NaSS-MAA-MMA cation exchange membranes for membrane capacitive deionization (MCDI), Desalination, 285 (2012) 138-146.

[13] Y. Zhao, Y. Wang, R. Wang, Y. Wu, S. Xu, J. Wang, Performance comparison and energy consumption analysis of capacitive deionization and membrane capacitive deionization processes, Desalination, 324 (2013) 127-133.

[14] S.-i. Jeon, H.-r. Park, J.-g. Yeo, S. Yang, C.H. Cho, M.H. Han, D.K. Kim, Desalination via a new membrane capacitive deionization process utilizing flow-electrodes, Energy \& Environmental Science, 6 (2013) 1471-1475.

[15] M. Suss, S. Porada, X. Sun, P. Biesheuvel, J. Yoon, V. Presser, Water desalination via capacitive deionization: what is it and what can we expect from it?, Energy \& Environmental Science, 8 (2015) 2296-2319.

[16] I. Villar, D.J. Suarez-De la Calle, Z. González, M. Granda, C. Blanco, R. Menéndez, R. Santamaría, Carbon materials as electrodes for electrosorption of $\mathrm{NaCl}$ in aqueous solutions, Adsorption, 17 (2011) 467-471.

[17] S. Porada, L. Weinstein, R. Dash, A. Van Der Wal, M. Bryjak, Y. Gogotsi, P. Biesheuvel, Water desalination using capacitive deionization with microporous carbon electrodes, ACS applied materials \& interfaces, 4 (2012) 1194-1199.

[18] E. Frackowiak, F. Beguin, Carbon materials for the electrochemical storage of energy in capacitors, Carbon, 39 (2001) 937-950.

[19] H. Li, L. Pan, T. Lu, Y. Zhan, C. Nie, Z. Sun, A comparative study on electrosorptive behavior of carbon nanotubes and graphene for capacitive deionization, Journal of Electroanalytical Chemistry, 653 (2011) 40-44.

[20] C. Hou, C. Huang, C. Hu, Application of capacitive deionization technology to the removal of sodium chloride from aqueous solutions, International Journal of Environmental Science and Technology, 10 (2013) 753-760.

[21] H. Pröbstle, M. Wiener, J. Fricke, Carbon aerogels for electrochemical double layer capacitors, Journal of Porous Materials, 10 (2003) 213-222.

[22] Y. Liu, L. Pan, X. Xu, T. Lu, Z. Sun, D.H. Chua, Enhanced desalination efficiency in modified membrane capacitive deionization by introducing ion-exchange polymers in carbon nanotubes electrodes, Electrochimica Acta, 130 (2014) 619-624.

[23] W. Zhang, M. Mossad, L. Zou, A study of the long-term operation of capacitive deionisation in inland brackish water desalination, Desalination, 320 (2013) 80-85.

[24] M. Mossad, W. Zhang, L. Zou, Using capacitive deionisation for inland brackish groundwater desalination in a remote location, Desalination, 308 (2013) 154-160.

[25] K. Laxman, M.T.Z. Myint, M. Al Abri, P. Sathe, S. Dobretsov, J. Dutta, Desalination and disinfection of inland brackish ground water in a capacitive deionization cell using nanoporous activated carbon cloth electrodes, Desalination, 362 (2015) 126-132.

[26] Z.-H. Huang, M. Wang, L. Wang, F. Kang, Relation between the charge efficiency of activated carbon fiber and its desalination performance, Langmuir, 28 (2012) 5079-5084.

[27] P. Xu, J.E. Drewes, D. Heil, G. Wang, Treatment of brackish produced water using carbon aerogel-based capacitive deionization technology, Water Research, 42 (2008) 2605-2617.

[28] C.H. Hou, C.Y. Huang, C.Y. Hu, Application of capacitive deionization technology to the removal of sodium chloride from aqueous solutions, International Journal of Environmental Science and Technology, 10 (2013) 753-760. 
[29] D.K. Kohli, S. Bhartiya, A. Singh, R. Singh, M.K. Singh, P.K. Gupta, Capacitive deionization of ground water using carbon aerogel based electrodes, Desalination and Water Treatment, 57 (2016) 26871-26879.

[30] J.-B. Lee, K.-K. Park, S.-W. Yoon, P.-Y. Park, K.-I. Park, C.-W. Lee, Desalination performance of a carbon-based composite electrode, Desalination, 237 (2009) 155-161.

[31] X. Wen, D. Zhang, L. Shi, T. Yan, H. Wang, J. Zhang, Three-dimensional hierarchical porous carbon with a bimodal pore arrangement for capacitive deionization, Journal of Materials Chemistry, 22 (2012) 23835-23844.

[32] L. Liu, L. Liao, Q. Meng, B. Cao, High performance graphene composite microsphere electrodes for capacitive deionisation, Carbon, 90 (2015) 75-84.

[33] G.X. Li, P.X. Hou, S.Y. Zhao, C. Liu, H.M. Cheng, A flexible cotton-derived carbon sponge for high-performance capacitive deionization, Carbon, 101 (2016) 1-8.

[34] C. Tsouris, R. Mayes, J. Kiggans, K. Sharma, S. Yiacoumi, D. Depaoli, S. Dai, Mesoporous carbon for capacitive deionization of saline water, Environmental Science and Technology, 45 (2011) 10243-10249.

[35] Q. Liu, Y. Wang, Y. Zhang, S. Xu, J. Wang, Effect of dopants on the adsorbing performance of polypyrrole/graphite electrodes for capacitive deionization process, Synthetic Metals, 162 (2012) 655-661.

[36] P. Długołęcki, A. van der Wal, Energy recovery in membrane capacitive deionization, Environmental science \& technology, 47 (2013) 4904-4910.

[37] B. van Limpt, A. van der Wal, Water and chemical savings in cooling towers by using membrane capacitive deionization, Desalination, 342 (2014) 148-155.

[38] J.-B. Lee, K.-K. Park, H.-M. Eum, C.-W. Lee, Desalination of a thermal power plant wastewater by membrane capacitive deionization, Desalination, 196 (2006) 125-134.

[39] H. Li, Y. Gao, L. Pan, Y. Zhang, Y. Chen, Z. Sun, Electrosorptive desalination by carbon nanotubes and nanofibres electrodes and ion-exchange membranes, Water research, 42 (2008) 4923-4928.

[40] P. Liang, L. Yuan, X. Yang, S. Zhou, X. Huang, Coupling ion-exchangers with inexpensive activated carbon fiber electrodes to enhance the performance of capacitive deionization cells for domestic wastewater desalination, Water research, 47 (2013) 2523-2530. [41] H. Lee, Y. Jin, S. Hong, Recent transitions in ultrapure water (UPW) technology: Rising role of reverse osmosis (RO), Desalination, 399 (2016) 185-197.

[42] Y. Jande, M. Minhas, W. Kim, Ultrapure water from seawater using integrated reverse osmosis-capacitive deionization system, Desalination and Water Treatment, 53 (2015) 34823490.

[43] M. Minhas, Y. Jande, W. Kim, Combined reverse osmosis and constant-current operated capacitive deionization system for seawater desalination, Desalination, 344 (2014) 299-305.

[44] L. Lee, H. Ng, S. Ong, J. Hu, G. Tao, K. Kekre, B. Viswanath, W. Lay, H. Seah, Capacitive Deionization for RO brine recovery in NEWater production, Water Practice and Technology, 3 (2008) wpt2008081.

[45] J.-H. Lee, J.-H. Choi, The production of ultrapure water by membrane capacitive deionization (MCDI) technology, Journal of membrane science, 409 (2012) 251-256.

[46] Y. Jande, W. Kim, Predicting the lowest effluent concentration in capacitive deionization, Separation and Purification Technology, 115 (2013) 224-230.

[47] Ö. Arar, Ü. Yüksel, N. Kabay, M. Yüksel, Application of electrodeionization (EDI) for removal of boron and silica from reverse osmosis (RO) permeate of geothermal water, Desalination, 310 (2013) 25-33. 
[48] P. Dorji, J. Choi, D.I. Kim, S. Phuntsho, S. Hong, H.K. Shon, Membrane capacitive deionisation as an alternative to the 2 nd pass for seawater reverse osmosis desalination plant for bromide removal, Desalination, 433 (2018) 113-119.

[49] P.V. Brady, R.J. Kottenstette, T.M. Mayer, M.M. Hightower, Inland desalination: challenges and research needs, Journal of Contemporary Water Research \& Education, 132 (2005) 46-51.

[50] S. Adham, J. Oppenheimer, M. Kumar, Innovative approaches to RO concentrate management: Beneficial reuse and concentrate minimization, Proceedings of the Water Environment Federation, 2006 (2006) 4334-4344.

[51] J. Yu, J. Qin, K.A. Kekre, B. Viswanath, G. Tao, H. Seah, Impact of operating conditions on performance of capacitive deionisation for reverse osmosis brine recovery, Journal of Water Reuse and Desalination, 4 (2014) 59-64.

[52] L.Y. Lee, H.Y. Ng, S.L. Ong, G. Tao, K. Kekre, B. Viswanath, W. Lay, H. Seah, Integrated pretreatment with capacitive deionization for reverse osmosis reject recovery from water reclamation plant, Water research, 43 (2009) 4769-4777.

[53] M.B. Minhas, Y.A. Jande, W.S. Kim, Hybrid Reverse Osmosis- Capacitive Deionization versus Two- Stage Reverse Osmosis: A Comparative Analysis, Chemical Engineering \& Technology, 37 (2014) 1137-1145.

[54] A.D. Benetti, Water reuse: issues, technologies, and applications, Engenharia Sanitaria e Ambiental, 13 (2008) 247-248.

[55] S.-J. Seo, H. Jeon, J.K. Lee, G.-Y. Kim, D. Park, H. Nojima, J. Lee, S.-H. Moon, Investigation on removal of hardness ions by capacitive deionization (CDI) for water softening applications, Water research, 44 (2010) 2267-2275.

[56] A. Johnson, J. Newman, Desalting by means of porous carbon electrodes, Journal of the Electrochemical Society, 118 (1971) 510-517.

[57] P. Xu, J.E. Drewes, D. Heil, G. Wang, Treatment of brackish produced water using carbon aerogel-based capacitive deionization technology, Water research, 42 (2008) 2605-2617.

[58] L. Pan, X. Wang, Y. Gao, Y. Zhang, Y. Chen, Z. Sun, Electrosorption of anions with carbon nanotube and nanofibre composite film electrodes, Desalination, 244 (2009) 139-143.

[59] H. Yoon, J. Lee, S.-R. Kim, J. Kang, S. Kim, C. Kim, J. Yoon, Capacitive deionization with Ca-alginate coated-carbon electrode for hardness control, Desalination, 392 (2016) 46-53. [60] T.N. Tuan, S. Chung, J.K. Lee, J. Lee, Improvement of water softening efficiency in capacitive deionization by ultra purification process of reduced graphene oxide, Current Applied Physics, 15 (2015) 1397-1401.

[61] B. Dong, Z. Zhang, L. Wang, H. Zhang, C. Chang, Electrosorption of hardness ions from water with activated carbon cloth electrodes, Asian Journal of Chemistry, 27 (2015) 2082-2086. [62] C.-H. Hou, C.-Y. Huang, A comparative study of electrosorption selectivity of ions by activated carbon electrodes in capacitive deionization, Desalination, 314 (2013) 124-129.

[63] J.J. Wouters, M.I. Tejedor-Tejedor, J.J. Lado, R. Perez-Roa, M.A. Anderson, Influence of Metal Oxide Coatings, Carbon Materials and Potentials on Ion Removal in Capacitive Deionization, Journal of The Electrochemical Society, 165 (2018) E148-E161.

[64] J.J. Lado, R.E. Pérez-Roa, J.J. Wouters, M.I. Tejedor-Tejedor, M.A. Anderson, Evaluation of operational parameters for a capacitive deionization reactor employing asymmetric electrodes, Separation and Purification Technology, 133 (2014) 236-245.

[65] J.J. Wouters, J.J. Lado, M.I. Tejedor-Tejedor, R. Perez-Roa, M.A. Anderson, Carbon fiber sheets coated with thin-films of $\mathrm{SiO} 2$ and $\gamma$-Al2O 3 as electrodes in capacitive deionization: Relationship between properties of the oxide films and electrode performance, Electrochimica Acta, 112 (2013) 763-773. 
[66] J.J. Lado, J.J. Wouters, M.I. Tejedor-Tejedor, M.A. Anderson, E. García-Calvo, Asymmetric capacitive deionization utilizing low surface area carbon electrodes coated with nanoporous thin-films of Al2O3 and SiO2, Journal of The Electrochemical Society, 160 (2013) E71-E78.

[67] S.J. Seo, H. Jeon, J.K. Lee, G.Y. Kim, D. Park, H. Nojima, J. Lee, S.H. Moon, Investigation on removal of hardness ions by capacitive deionization (CDI) for water softening applications, Water Research, 44 (2010) 2267-2275.

[68] C. Kim, J. Lee, S. Kim, J. Yoon, Electrochemical softening using capacitive deionization (CDI) with zeolite modified carbon electrode (ZMCE), Desalination and Water Treatment, 57 (2016) 24682-24687.

[69] J. Choi, H. Lee, S. Hong, Capacitive deionization (CDI) integrated with monovalent cation selective membrane for producing divalent cation-rich solution, Desalination, 400 (2016) 3846.

[70] M. Mossad, L. Zou, Study of fouling and scaling in capacitive deionisation by using dissolved organic and inorganic salts, Journal of hazardous materials, 244 (2013) 387-393.

[71] M. Reig, S. Casas, O. Gibert, C. Valderrama, J. Cortina, Integration of nanofiltration and bipolar electrodialysis for valorization of seawater desalination brines: production of drinking and waste water treatment chemicals, Desalination, 382 (2016) 13-20.

[72] O. Lahav, L. Birnhack, Quality criteria for desalinated water following post-treatment, Desalination, 207 (2007) 286-303.

[73] P. Rana-Madaria, M. Nagarajan, C. Rajagopal, B.S. Garg, Removal of chromium from aqueous solutions by treatment with carbon aerogel electrodes using response surface methodology, Industrial \& engineering chemistry research, 44 (2005) 6549-6559.

[74] F. Fu, Q. Wang, Removal of heavy metal ions from wastewaters: a review, Journal of environmental management, 92 (2011) 407-418.

[75] P. Liu, T. Yan, J. Zhang, L. Shi, D. Zhang, Separation and recovery of heavy metal ions and salt ions from wastewater by $3 \mathrm{D}$ graphene-based asymmetric electrodes via capacitive deionization, Journal of Materials Chemistry A, 5 (2017) 14748-14757.

[76] C.-S. Fan, S.-C. Tseng, K.-C. Li, C.-H. Hou, Electro-removal of arsenic (III) and arsenic (V) from aqueous solutions by capacitive deionization, Journal of hazardous materials, 312 (2016) 208-215.

[77] Z. Huang, L. Lu, Z. Cai, Z.J. Ren, Individual and competitive removal of heavy metals using capacitive deionization, Journal of hazardous materials, 302 (2016) 323-331.

[78] W. Zhang, M. Mossad, J.S. Yazdi, L. Zou, A statistical experimental investigation on arsenic removal using capacitive deionization, Desalination and Water Treatment, 57 (2016) 3254-3260.

[79] S. Garrido, M. Avilés, A. Ramírez, C. Calderón, A. Ramírez-Orozco, A. Nieto, G. Shelp, L. Seed, M. Cebrian, E. Vera, Arsenic removal from water of Huautla, Morelos, Mexico using capacitive deionization, Natural arsenic in Groundwaters. of Latin. America; Taylor \& Francis Group: London, UK, (2009) 665-676.

[80] J.C. Farmer, S.M. Bahowick, J.E. Harrar, D.V. Fix, R.E. Martinelli, A.K. Vu, K.L. Carroll, Electrosorption of chromium ions on carbon aerogel electrodes as a means of remediating ground water, Energy \& fuels, 11 (1997) 337-347.

[81] S.Y. Huang, C.S. Fan, C.H. Hou, Electro-enhanced removal of copper ions from aqueous solutions by capacitive deionization, Journal of hazardous materials, 278 (2014) 8-15.

[82] D.J. Conley, H.W. Paerl, R.W. Howarth, D.F. Boesch, S.P. Seitzinger, E. Karl, E. Karl, C. Lancelot, E. Gene, E. Gene, Controlling eutrophication: nitrogen and phosphorus, Science, 123 (2009) 1014-1015. 
[83] D. Majumdar, N. Gupta, Nitrate pollution of groundwater and associated human health disorders, Indian Journal of Environmental Health, 42 (2000) 28-39.

[84] D. Cordell, A. Rosemarin, J.J. Schröder, A. Smit, Towards global phosphorus security: A systems framework for phosphorus recovery and reuse options, Chemosphere, 84 (2011) 747 758.

[85] B. Cieślik, P. Konieczka, A review of phosphorus recovery methods at various steps of wastewater treatment and sewage sludge management. The concept of "no solid waste generation" and analytical methods, Journal of Cleaner Production, 142 (2017) 1728-1740.

[86] S. Shams, Assessing innovative technologies for nitrate removal from drinking water, in, University of Waterloo, 2010.

[87] G.-H. Huang, T.-C. Chen, S.-F. Hsu, Y.-H. Huang, S.-H. Chuang, Capacitive deionization (CDI) for removal of phosphate from aqueous solution, Desalination and Water Treatment, 52 (2014) 759-765.

[88] W. Tang, P. Kovalsky, D. He, T.D. Waite, Fluoride and nitrate removal from brackish groundwaters by batch-mode capacitive deionization, Water research, 84 (2015) 342-349.

[89] R. Broséus, J. Cigana, B. Barbeau, C. Daines-Martinez, H. Suty, Removal of total dissolved solids, nitrates and ammonium ions from drinking water using charge-barrier capacitive deionisation, Desalination, 249 (2009) 217-223.

[90] Y.-J. Kim, J.-H. Choi, Selective removal of nitrate ion using a novel composite carbon electrode in capacitive deionization, Water research, 46 (2012) 6033-6039.

[91] J.-H. Yeo, J.-H. Choi, Enhancement of nitrate removal from a solution of mixed nitrate, chloride and sulfate ions using a nitrate-selective carbon electrode, Desalination, 320 (2013) $10-16$.

[92] J.J. Lado, R.E. Pérez-Roa, J.J. Wouters, M.I. Tejedor-Tejedor, C. Federspill, J.M. Ortiz, M.A. Anderson, Removal of nitrate by asymmetric capacitive deionization, Separation and Purification Technology, 183 (2017) 145-152.

[93] C. Hu, J. Dong, T. Wang, R. Liu, H. Liu, J. Qu, Nitrate electro-sorption/reduction in capacitive deionization using a novel $\mathrm{Pd} / \mathrm{NiAl}$-layered metal oxide film electrode, Chemical Engineering Journal, 335 (2018) 475-482.

[94] E. Avraham, B. Yaniv, A. Soffer, D. Aurbach, Developing ion electroadsorption stereoselectivity, by pore size adjustment with chemical vapor deposition onto active carbon fiber electrodes. Case of $\mathrm{Ca} 2+/ \mathrm{Na}+$ separation in water capacitive desalination, The Journal of Physical Chemistry C, 112 (2008) 7385-7389.

[95] M.A. Anderson, A.L. Cudero, J. Palma, Capacitive deionization as an electrochemical means of saving energy and delivering clean water. Comparison to present desalination practices: Will it compete?, Electrochimica Acta, 55 (2010) 3845-3856.

[96] R. Zhao, P. Biesheuvel, A. Van der Wal, Energy consumption and constant current operation in membrane capacitive deionization, Energy \& Environmental Science, 5 (2012) 9520-9527.

[97] S.-i. Jeon, J.-g. Yeo, S. Yang, J. Choi, D.K. Kim, Ion storage and energy recovery of a flow-electrode capacitive deionization process, Journal of Materials Chemistry A, 2 (2014) 6378-6383.

[98] O.N. Demirer, R.M. Naylor, C.A.R. Perez, E. Wilkes, C. Hidrovo, Energetic performance optimization of a capacitive deionization system operating with transient cycles and brackish water, Desalination, 314 (2013) 130-138.

[99] A. Pernia, F.J. Alvarez-Gonzalez, M.A. Prieto, P.J. Villegas, F. Nuno, New Control Strategy of an Up-Down Converter for Energy Recovery in a CDI Desalination System, IEEE Transactions on Power Electronics, 29 (2014) 3573-3581. 
[100] L. Han, K. Karthikeyan, K.B. Gregory, Energy consumption and recovery in capacitive deionization using nanoporous activated carbon electrodes, Journal of The Electrochemical Society, 162 (2015) E282-E288.

[101] G.L. Andres, Y. Yoshihara, A capacitive deionization system with high energy recovery and effective re-use, Energy, 103 (2016) 605-617.

[102] J. Kang, T. Kim, H. Shin, J. Lee, J.-I. Ha, J. Yoon, Direct energy recovery system for membrane capacitive deionization, Desalination, 398 (2016) 144-150.

[103] F.J. Álvarez-González, J.A. Martín-Ramos, J. Díaz, J.A. Martínez, A.M. Pernía, Energyrecovery optimization of an experimental CDI desalination system, IEEE Transactions on Industrial Electronics, 63 (2016) 1586-1597.

[104] E. García-Quismondo, C. Santos, J. Lado, J.s. Palma, M.A. Anderson, Optimizing the energy efficiency of capacitive deionization reactors working under real-world conditions, Environmental science \& technology, 47 (2013) 11866-11872.

[105] R. Zhao, S. Porada, P. Biesheuvel, A. Van der Wal, Energy consumption in membrane capacitive deionization for different water recoveries and flow rates, and comparison with reverse osmosis, Desalination, 330 (2013) 35-41.

[106] M.M. Pendergast, E.M. Hoek, A review of water treatment membrane nanotechnologies, Energy \& Environmental Science, 4 (2011) 1946-1971.

[107] J.W. Post, J. Veerman, H.V. Hamelers, G.J. Euverink, S.J. Metz, K. Nymeijer, C.J. Buisman, Salinity-gradient power: Evaluation of pressure-retarded osmosis and reverse electrodialysis, Journal of membrane science, 288 (2007) 218-230.

[108] Y.A.C. Jande, W.-S. Kim, Simultaneous production of freshwater and energy from saline water using hybrid capacitive deionization-reverse electrodialysis, Int. J. Res. Chem. Metall. Civ. Eng., 1 (2014) 35-39.

[109] Y. Jande, W. Kim, Integrating reverse electrodialysis with constant current operating capacitive deionization, Journal of environmental management, 146 (2014) 463-469.

[110] B.E. Logan, B. Hamelers, R. Rozendal, U. Schröder, J. Keller, S. Freguia, P. Aelterman, W. Verstraete, K. Rabaey, Microbial fuel cells: methodology and technology, Environmental science \& technology, 40 (2006) 5181-5192.

[111] Z. Du, H. Li, T. Gu, A state of the art review on microbial fuel cells: a promising technology for wastewater treatment and bioenergy, Biotechnology advances, 25 (2007) 464482.

[112] C. Feng, C.-H. Hou, S. Chen, C.-P. Yu, A microbial fuel cell driven capacitive deionization technology for removal of low level dissolved ions, Chemosphere, 91 (2013) 623628.

[113] L. Yuan, X. Yang, P. Liang, L. Wang, Z.-H. Huang, J. Wei, X. Huang, Capacitive deionization coupled with microbial fuel cells to desalinate low-concentration salt water, Bioresource technology, 110 (2012) 735-738.

[114] M. Mehanna, T. Saito, J. Yan, M. Hickner, X. Cao, X. Huang, B.E. Logan, Using microbial desalination cells to reduce water salinity prior to reverse osmosis, Energy \& Environmental Science, 3 (2010) 1114-1120.

[115] X. Cao, X. Huang, P. Liang, K. Xiao, Y. Zhou, X. Zhang, B.E. Logan, A new method for water desalination using microbial desalination cells, Environmental science \& technology, 43 (2009) 7148-7152.

[116] C. Forrestal, P. Xu, Z. Ren, Sustainable desalination using a microbial capacitive desalination cell, Energy \& Environmental Science, 5 (2012) 7161-7167.

[117] Q. Wen, H. Zhang, H. Yang, Z. Chen, J. Nan, Y. Feng, Improving desalination by coupling membrane capacitive deionization with microbial desalination cell, Desalination, 354 (2014) 23-29. 
[118] Z.A. Stoll, C. Forrestal, Z.J. Ren, P. Xu, Shale gas produced water treatment using innovative microbial capacitive desalination cell, Journal of hazardous materials, 283 (2015) 847-855.

[119] E. García-Quismondo, C. Santos, J. Soria, J.s. Palma, M.A. Anderson, New operational modes to increase energy efficiency in capacitive deionization systems, Environmental science \& technology, 50 (2016) 6053-6060.

[120] Y.-J. Kim, J.-H. Choi, Enhanced desalination efficiency in capacitive deionization with an ion-selective membrane, Separation and Purification Technology, 71 (2010) 70-75.

[121] J.B. Lee, K.K. Park, H.M. Eum, C.W. Lee, Desalination of a thermal power plant wastewater by membrane capacitive deionization, Desalination, 196 (2006) 125-134.

[122] P. Biesheuvel, A. Van der Wal, Membrane capacitive deionization, Journal of Membrane Science, 346 (2010) 256-262.

[123] P. Xu, J.E. Drewes, D. Heil, G. Wang, Treatment of brackish produced water using carbon aerogel-based capacitive deionization technology, Water research, 42 (2008) 26052617. 